WINPEC Working Paper Series No.E1423

March 2015

The Certification Role of Pre-IPO Banking Relationships:

IPO Underpricing and Post-IPO Performance in Japan

Yoshiaki Ogura

Waseda INstitute of Political EConomy

Waseda University

Tokyo,Japan 


\title{
The Certification Role of Pre-IPO Banking Relationships: IPO Underpricing and Post-IPO Performance in Japan *
}

\author{
Yoshiaki Ogura ${ }^{\dagger}$ \\ School of Political Science and Economics, Waseda University, \\ 1-6-1 Nishi Waseda, Shinjuku-ku, Tokyo 169-8050, JAPAN
}

This version: March 2015

\begin{abstract}
We find empirical evidence that pre-IPO relationships with commercial banks through lending and investment via their venture capital subsidiaries significantly reduces IPO underpricing, whereas the affiliation between a lead underwriter and venture backing the IPO company does not. We also obtain evidence for lower post-IPO risk and return for firms with a pre-IPO banking relationship. These findings suggest that a pre-IPO banking relationship certifies the low risk of an IPO firm, whereas investors' concerns about conflicts of interest are not significant. Given the fact that institutional investors are a minority in the allocation of IPO stocks in Japan, the former effect is expected to come mainly from reducing either the investors' winner's curse or the signaling incentive of IPO firms, rather than from the reduction in the information rent for institutional investors participating in the book-building process.
\end{abstract}

JEL classification number: G21, L14, D82.

Key words: IPO underpricing, winner's curse, information revelation, conflict of interests, relationship banking.

\footnotetext{
${ }^{*}$ I am grateful for the insightful comments provided by Sheng-Hung Chen, Konari Uchida, and participants in seminars at Chuo University, Research Institute of Economy, Trade and Industry, Ritsumeikan University, and those in the sessions in the 21st Nippon Finance Association Meeting at Chuo University, Tokyo Japan, and the 2014 Asian Finance Association Conference at Nusa Dua, Indonesia. I am also very grateful for the industrious research assistance by Naoto Soda and Jiangtao Fu. This study is financially supported by KAKENHI 23243050 and 50273561.

${ }^{\dagger}$ E-mail address: yogura@waseda.jp.
} 


\section{Introduction}

So called firewall deregulation since the late 1990s has increasingly allowed sharing private corporate clients' information between the investment and commercial banking areas within a financial conglomerate in countries such as the United States and Japan, leading to concerns that conflict of interests between commercial and investment banking may reemerge. However, most empirical studies provide evidence to the contrary (Kroszner and Rajan, 1994; Puri, 1996; Gompers and Lerner, 1999). Supporters argue that it improves efficiency in the investment banking market. For example, an investment bank can use commercial banks' proprietary information accumulated through long-term lending relationships with corporate clients while underwriting securities. ${ }^{1}$

In this context, many researchers have conducted theoretical and empirical studies seeking evidence for the usefulness of commercial banks' private information for investment banks' initial public offering of stocks, an important investment banking service. The seminal paper by James and Wier (1990) presents an analytical model showing that a pre-IPO lending relationship with a bank signals low risk for an IPO firm and provides evidence, i.e., the negative impact of a pre-IPO loan on the initial return of IPO stocks. Puri (1999) presents an analytical model in which there is a tension between the benefits of information sharing and the potential conflict of interest between commercial banking and underwriting. The study shows that a commercial bank can play a certification role in underwriting securities, though this is less effective when the bank holds equity rather than debt, and the size of its stake is larger due to an increased concern about a conflict of interest. Schenone (2004) also presents evidence showing the informational advantage of IPO underwriters who are affiliated with a bank that has extended a loan to an IPO firm. Empirical studies using a more recent dataset of the initial returns and the post-IPO long-term financial or stock performance (e.g., Barry and Mihov, 2005; Gonzalez and James, 2007; Benzoni and Schenone, 2010) also reinforce the evidence of the certification role of the

\footnotetext{
${ }^{1}$ The existing literature provides empirical evidence for banks' information advantage (e.g., James, 1987; Lummer and MacConnell, 1989; Petersen and Rajan, 1994; Berger and Udell, 1995; Mester et al., 2007; Dass and Massa, 2011; Norden and Weber, 2010; Bharath et al., 2011).
} 
pre-IPO banking relationship. ${ }^{2}$

This study contributes evidence reinforcing the certification effect of the pre-IPO banking relationship by examining both the underpricing and the post-IPO operating and market performance in the non-U.S. market after the firewall deregulation. The benefits of using a Japanese IPO dataset are twofold. First, almost all IPOs in Japan have been offered through book building since 1997, a process comparable with that in the U.S., but the composition of investors participating in IPOs differs significantly. The majority of Japanese IPOs are allocated to individual investors, who are presumably uninformed, while the majority in the U.S. are allocated to institutional investors, who are presumably better informed. Thus, IPO underpricing is more likely to be driven by the winner's curse (Rock, 1986) or the issuers' signaling motivation (Allen and Faulhaber, 1989; Grinblatt and Huang, 1989; Welch, 1989) in Japan. A comparison of the empirical results from the U.S. and Japan allow an identification of the mechanism behind the certification role of the pre-IPO banking relationship.

Secondly, it is possible to identify the venture capitalists (VCs) that have invested in each financing round up to IPO in our dataset, which is provided by Japan Venture Research Co., Ltd. (JVR). Furthermore, it is possible to identify the parent financial institution of each VC by combining the subsidiary information of each financial institution. Thus, it is possible to determine whether a bank has a pre-IPO relationship with a firm not only through loans but also through equity via its VC subsidiaries and whether a lead underwriter has a pre-IPO relationship with an IPO firm through its VC subsidiaries. This unique information clarifies the source of the certification role of the pre-IPO banking relationship: whether it emerges through loans or affiliated VC investments, and whether the effect emerges by reducing the underwriter's

\footnotetext{
${ }^{2}$ Outside the U.S., Ber et al. (2001) find that less or even negative underpricing if the underwriter is also a large creditor using Israeli data from the 1990s. They also find that IPO "overpricing" is more prominent when an investment fund affiliated with the underwriter purchases the IPO stocks. They conclude that a conflict of interest does exist in the sense that an IPO underwriter enjoys a reputation from potential issuers at the cost of the investors for the investment fund affiliated with the underwriter. Hamao et al. (2000) also find evidence substantiating investors' concerns about conflict of interests, i.e., there is less IPO underpricing if a lead underwriter is a security house whose VC subsidiary has not invested before the IPO, by examining Japanese IPO underpricing from 1989 to 1995 where all IPOs were conducted by auction and information sharing between the commercial and investment banking sections was banned. On the other hand, Arikawa and Imad'eddine (2010) find that the IPO underpricing is significantly smaller when the underwriter's VC subsidiary invested directly before the IPO using a more recent dataset from the 2000s, where all IPOs were offered by book building.
} 
necessity for information revealed by informed investors during book building (Benveniste and Spindt, 1989), the reduction in the uninformed investors' winner's curse, or the issuers' signaling motivation.

To test the certification role of the pre-IPO banking relationship, which decreases the information asymmetry between uninformed and informed investors and/or between uninformed underwriters and informed institutional investors, we apply a statistical test of whether the preIPO banking relationship reduces initial returns, that is, IPO underpricing, by using a dataset of VC-backed IPO firms in Japan from 2002 to 2013. The dataset is collected from the period after the deregulation of information sharing among investment banking, commercial banking, and VC subsidiaries within a financial conglomerate, and another regulatory change allowing banks' VC subsidiaries to hold more than 5 percent of the voting rights of non-financial venture businesses, which are less than 5 years old (see Section 2.2 for details of these regulatory changes). Thus, an affiliation between VCs and underwriters can legally facilitate information sharing during the period under investigation. In addition, bank-affiliated VCs could work as substantial venture capitalists and can also legally share information with parent banks.

We first regress the initial return of IPOs to various pre-IPO banking-relationship measures with control variables suggested in the current literature. The results of OLS and 2SLS show that IPO underpricing is significantly lower when a firm receives both a pre-IPO loan and a bank-affiliated VC investment than otherwise. This difference is smaller if a firm receives either bank loans or bank-affiliated VC investments only. The sample mean of IPO underpricing in our dataset is about $87 \%$. The pre-IPO banking relationship through both loans and investments reduces it by about 20 points. Thus, the effect is both statistically and economically significant.

On the other hand, we do not find any significant impact of an affiliation of the lead underwriter and a VC on IPO underpricing. We can interpret this result as evidence that investors take potential conflict of interest into account, or that the underwriter's needs to compensate for information revealed by informed institutional investors (Benveniste and Spindt, 1989) is not sufficient to explain the IPO underpricing. In light of the fact that individual investors, who 
are presumably uninformed and naive, are a majority in the Japanese IPO market, ${ }^{3}$ the latter interpretation seems more reasonable in this context.

As for the characteristics of firms with pre-IPO banking relationships, firms are more likely to have a banking relationship if it is large and well-established, as found by Sun et al. (2013). In addition, firms that are less profitable, located outside of the metropolitan area or with a higher tangible asset ratio are more likely to have a pre-IPO banking relationship. The latter finding is consistent with the theoretical prediction by Andrieu and Groh (2012) that firms with higher liquidation values are likely to choose a bank-affiliated VC.

Second, we examine the difference in post-IPO performance between those with pre-IPO banking relationships and those without. The univariate analysis shows that those with a pre-IPO banking relationship exhibit low-risk low-return patterns in the stock market. Firms without pre-IPO banking relationships are significantly more profitable than those with one in the periods right before and after the IPO, but the profitability gap almost disappears three years after the IPO. The regression analysis, in particular, the 2SLS that takes into account the endogeneity of the banking relationship, provides evidence supporting these results, which are consistent with the hypothesized certification role of the pre-IPO banking relationship. The regression analysis also shows that those with a pre-IPO banking relationship maintain a higher ratio of borrowing over total assets, consistent with the existing evidence for the strategic portfolio choice of the bank-affiliated VCs (e.g., Hellmann et al., 2008; Konishi and Suzuki, 2007; Sun and Uchida, 2013).

Taken together, this study's findings suggest that the pre-IPO banking relationship works as a certification of the low risk of an IPO firm for uninformed investors. On this point, the pre-IPO banking relationship contributes to economic efficiency by minimizing the financing costs for IPO firms by reducing IPO underpricing, that is, the money left on the table. On the other hand, the pre-IPO banking relationship also deters economic efficiency at the point that the portfolios of banks or their VC subsidiaries deviate from the socially optimal portfolio

\footnotetext{
${ }^{3}$ Funaoka (2008) shows that $74.1 \%$ of IPO stocks in the period from August 2006 to December 2008 are allocated to individual investors in Japan.
} 
favoring those in sectors more dependent on bank loans.

The remaining part of this paper is organized as follows. Section 2 develops the empirical hypotheses from the existing theory about IPO underpricing. Section 3 describes the dataset and reports the IPO underpricing analysis, with the analysis of the post-IPO performance described in Section 4. Section 5 concludes the paper.

\section{Hypotheses}

\subsection{Theory of IPO Underpricing Based on Issuer's Quality}

The phenomenon wherein the first-day returns of an IPO stock, defined by the return from the offer price to the closing or opening price of the initial trading day, is significantly positive on average has been observed in many countries (e.g., Engelen and Essen, 2010). Many studies have proposed various explanations for this puzzling and persistent phenomenon. ${ }^{4}$ Among the many propositions, the most influential are based on the asymmetric information regarding an issuer's quality, including are the winner's curse hypothesis (Rock, 1986), the information revelation hypothesis (Benveniste and Spindt, 1989), and the signaling hypothesis (Allen and Faulhaber, 1989; Grinblatt and Huang, 1989; Welch, 1989).

Winner's curse. This hypothesis assumes that IPO market participants include investors who are informed about the true quality of the IPO firm and those who are uninformed. They submit a buy order at the underwriters' uniform posted price. The informed can avoid bad firms whereas the uninformed cannot make such a strategic move as they lack information. The uninformed are reluctant to purchase IPO offerings since they anticipate a loss resulting from such a disadvantage; their buy orders are more likely to be executed for the offerings of worse firms. If the underwriter needs to induce the uninformed to purchase the IPO offering to reach the fund raising target, the underwriter must discount the offer price. Rock (1986) asserts that such a discount in the offer price is the IPO underpricing.

The key assumption in the winner's curse hypothesis is the information asymmetry among

\footnotetext{
${ }^{4}$ Ljungqvist (2008) provides an extensive literature review.
} 
investors, which implies that underpricing should be smaller in a situation where investors are more likely to have identical information. For example, if investors can observe a pre-IPO banking relationship during the IPO process and the investors believe that banks tend to favor a less risky portfolio, the existing theories show that the pre-IPO banking relationship decreases underpricing (James and Wier, 1990; Puri, 1999).

Information revelation. This hypothesis focuses on the process of book building. An underwriter needs information about the true quality of an offering firm to set the offer price in order to maximize the funds raised from the number of stocks sold. However, informed investors or, presumably, institutional investors, have an incentive not to reveal good information in the book building process so they may purchase good stocks at a lower offer price. The underwriter must offer some compensation, in the form of IPO underpricing, to induce informed investors to reveal their information.

The key assumption in the information revelation hypothesis is the information asymmetry between underwriters and institutional investors, which implies that underpricing should be negligible if the underwriter is as informed as the informed investors. For example, if either a venture capitalist that has invested in the offering firm or a bank that has previously extended it a loan before the IPO is affiliated with the underwriter, the underwriter is more likely to obtain proprietary information about the firm. The information revelation hypothesis predicts that this affiliation reduces underpricing. Additionally, if the pre-IPO banking relationship signals low risk to both uninformed investors and the underwriter, the information revelation hypothesis again predicts that the pre-IPO banking relationship reduces IPO underpricing.

Signaling. This hypothesis (Allen and Faulhaber, 1989; Grinblatt and Huang, 1989; Welch, 1989 ) is based on the assumption that the issuing firm is informed about its growth potential while investors are not. A firm that expects a future stock issue via IPO is willing to make a costly signal about its growth potential to attract more investors and issue its stocks at a higher price in the future. By contrast, firms without growth expectations need not be concerned 
about conditions in a future stock issue, and so are unwilling to make a costly signal. IPO underpricing can serve as such a costly signal and generate a separating equilibrium where the IPO underpricing is observed only for a firm that is confident in its growth and likely to make a seasoned equity offering in the future.

These hypotheses consistently predict less IPO underpricing for IPO firms with less uncertainty. In terms of the relationship between a bank and a pre-IPO firm, if the IPO prospectus contains evidence that a bank or its subsidiary provided a loan or equity to the IPO firm, as is partially the case in Japan, ${ }^{5}$ and investors value the bank's ability to gather information, the lending or investment relationship between a bank and an IPO firm reduces the IPO underpricing (James and Wier, 1990; Puri, 1999). We therefore propose:

Hypothesis 1 (Certification Role of Bank Relationship) The pre-IPO banking relationship through equity or debt decreases IPO underpricing.

In terms of the relationship between pre-IPO financiers and an underwriter, if an IPO underwriter is affiliated with a pre-IPO financier such as a bank or a VC subsidiary and shares private information about the firm, the information revelation hypothesis predicts less underpricing than when this relationship does not exist as long as investors' fear of conflict of interests is not significant.

Hypothesis 2 (Information Revelation Hypothesis) IPO underpricing is smaller if a venture capitalist that has invested in the IPO firm is a company affiliated with the underwriter.

If hypothesis 1 is rejected, it implies that none of the three hypotheses based on asymmetric information about the issuer's quality can explain IPO underpricing, or that the pre-IPO banking relationship does not have any certification role. Rejecting hypothesis 2 implies that the information revelation hypothesis is unsupported, or it supports investors' concern for the conflicts of interests.

\footnotetext{
${ }^{5}$ The IPO prospectus in Japan always includes the names of large shareholders, but does not always include the names of large lenders, despite the presence of debt in the balance sheet.
} 
To investigate hypothesis 1 , we will examine whether firms with a pre-IPO banking relationship actually exhibit less risk in the post-IPO performance.

Hypothesis 3 (Post-IPO Performance) There is less risk in the post-IPO performance of firms with a pre-IPO banking relationship through equity or debt.

\subsection{Institutional Background}

We test the above hypotheses by using the dataset collected from the Japanese IPO market. There are three noteworthy features of this market that impact the interpretation of the empirical findings.

Bank-Affiliated VCs. ${ }^{6}$ The regulation ${ }^{7}$ banned subsidiaries of commercial banks from holding more than a 5 percent voting share of a non-financial firm until December 1998. Therefore, commercial banks' venture-capital subsidiaries could neither be a majority shareholder nor an effective monitor for a startup company. The revision in December 1998 allows a bank to hold more than $5 \%$ of shares with voting rights in a non-financial company for at most 10 years through its subsidiary ${ }^{8}$ if the company is within 5 years after its founding and its $R \& D$ expenditure is more than $3 \%$ of either sales minus fixed assets or sales minus amounts of securities offerings. ${ }^{9}$ In other words, the deregulation in December 1998 eliminated the legal obstacle for bank subsidiaries to serve as an effective venture capitalist for R\&D-oriented startup firms.

Firewall Regulation. ${ }^{10}$ The Securities and Exchanges Law (article 65) in 1947 prohibited commercial banks from serving as an underwriter for security issues or a middleman in security trading. This regulation was in the same spirit as the Glass-Steagall Act in the U.S. to avoid a conflict of interest between the lending and underwriting businesses, and was partially removed by the 1992 revision that allowed banks to hold a subsidiary that performs underwriting and

\footnotetext{
${ }^{6}$ The reasoning in this paragraph is based mainly on Koyama (2012).

${ }^{7}$ Article 16-3, and Article 52-24 in the Banking Act, and Article 11 in the Anti-monopoly Law.

${ }^{8}$ Article 16-3 (7) in the revised Banking Act. This exception is expanded for companies within 10 years after its foundation in 2008.

${ }^{9}$ Article 16-2 (1) in the Banking Act, and Article 17-2 (6) in the Ordinance for Enforcement of the Banking Act.

${ }^{10}$ The reasoning in this paragraph is based mainly on Kondo et al. (2010).
} 
intermediation of security trading. Since then, banks were allowed to share private information about corporate clients between a parent bank and an investment banking subsidiary as long as they obtained written approval from the corporate client beforehand (Article 44-3 (1) (iv) in the Financial Instruments and Exchange Law). ${ }^{11}$ The investment banking subsidiary was prohibited from serving as a lead underwriter for a company over which the parent bank has a strong influence through a lending relationship, but such regulation, often called the "mainbank regulation," was abandoned in 1999. With the revision in 2009, banks were allowed to share corporate clients' private information without prior written approval except for items that the corporate clients specified as confidential information. Thus, information sharing between a parent bank and an underwriter, or between a $\mathrm{VC}$ and an underwriter within a financial group, has been increased since the 1990s in Japan. Besides, the revision in 2009 requires an organizational structure that avoid a conflict of interest, and to record the decision processes in the structure to address the potential conflicts.

Institutional Investors as a Minority in the Japanese IPO market. All IPOs in Japan are issued via book building since 1997, similar to that in the U.S. ${ }^{12}$ However, the markets are characterized by significant differenes the type of investors participating in the IPO market. The majority of IPO stocks are allocated to institutional investors in the U.S. For example, Aggarwal et al. (2002) shows that $72.8 \%$ of the IPO stocks in 1997 and 1998 were allocated to institutional investors. In contrast, Funaoka (2008) shows that $74.1 \%$ of the IPO stocks in the period from August 2006 to December 2008 were allocated to individual investors in Japan. This suggests that the information revelation motive is weaker, and the winner's curse motive is stronger in Japan than in the U.S. since it is less efficient to compensate institutional investors for revealing good information through underpricing for a group of investors who are mostly uninformed. Furthermore, this number suggests that underwriters face more urgency to induce individual investors to participate in IPOs in Japan than in the U.S.

\footnotetext{
${ }^{11}$ The Financial Instruments and Exchange Law, enacted in 2006, succeeds the Securities and Exchanges Law.

${ }^{12}$ Before 1997, IPOs in Japan were conducted through a hybrid-auction method (Kerins et al., 2007).
} 


\section{Test of IPO Underpricing}

\subsection{Data Source}

We focus on firms that have received VC investments and successfully reached IPO to test the hypotheses. The information about IPO firms with VC investment for calendar years 2002 to 2013 are collected from the Venture Business Finance Database, provided by the Japan Venture Research Co. Ltd. (JVR), which contains all VC-backed companies that went public in the stock exchanges for emerging companies within that period. ${ }^{13}$ The most notable feature of the dataset is that it contains detailed information about each round of staged financing, such as the names and identities (IDs) of investors and their affiliation type, e.g., commercial bank-affiliated, securities house-affiliated, or independent. The database also contains basic information from the IPO prospectus, such as shareholder structure, original JVR industry classification, and the head office location for each firm.

The information about IPOs is collected from the Stock Issuance at Market Price Database in the NIKKEI NEEDS Corporate Finance Database. The dataset contains the names and IDs of underwriters and the amount of underwriting for each, the offer price, the amount of funds raised, and the NIKKEI industry code. The information in the financial statements for five accounting periods prior to the IPO, including the amounts of outstanding loans and tangible assets, which are documented in the IPO prospectus, are collected from the Financial Statement Information of Non-Financial Companies Database in NIKKEI NEEDS. The stock market index, the JASDAQ index, is also collected from the Stock Price Information in NIKKEI NEEDS.

Data for 699 firms that went public between 2002 and 2013 is available from the JVR database. Among these, we dropped banks, security brokers, insurance companies, and stock exchanges (11 firms) since it is not possible to compare the financial statements of these com-

\footnotetext{
${ }^{13}$ The stock exchanges for emerging companies include Mothers (Tokyo Stock Exchange), JASDAQ, Heracules (Osaka Stock Exchange), NEO (Osaka Stock Exchange), Centrex (Nagoya Stock Exchange),Ambitious (Sapporo Stock Exchange), Q-Board (Fukuoka Stock Exchange). The database includes firms that went public in the Tokyo $A I M$ and TSE PRO markets (both are operated by Tokyo Stock Exchange), where only institutional investors trade stocks. We drop the firms in these markets since their financial information is not fully available. The database includes information about IPOs in 2001, however, the information is often incomplete for IPOs in this year.
} 
panies with other types of companies. We dropped a utility company since it is highly likely to be affected by government subsidies and other government policies (1 firm). We also dropped foreign companies whose financial information is not available in our database (2 firms), and companies that did not issue new stocks at IPO because the underwriter's share is not available (15 firms). We also exclude one firm that manipulated earnings at IPO and the one that reported extremely high initial returns of more than 4000\%. The resulting 668 IPO companies are the baseline sample for our analysis.

\subsection{Key Variables}

Initial return. Following the convention, we define the initial return by the rate of return from the offer price to the closing price on the first market trading day. Another definition is the rate of return from the offering price to the first initial price. We report the estimation results based on the former since the sample correlation coefficient between the initial returns of these alternative definitions is as high as 0.885 , and the estimation result is qualitatively identical for both definitions. ${ }^{14}$

Measures for the pre-IPO banking relationship. The JVR database clarifies the affiliations of VCs and other investors who invested at any round of equity financing before IPO. We construct a dummy variable, bank-VC affiliation equal to one if VCs or other pre-IPO investors are affiliated with a commercial bank in the JVR database and zero otherwise. ${ }^{15}$ This dummy variable captures the pre-IPO banking relationship through equity. We also construct a dummy variable, pre-IPO loan equal to one if a company has a positive borrowing balance at the end of the last accounting period before the IPO and zero otherwise. Loans to unlisted companies are more likely provided by banks or cooperative financial institutions, given that the Japanese financial system is highly dependent on banks and lacks "angels" for venture businesses, though it is not possible to completely deny the possibility that total borrowings include those from non-bank companies. To address this potential problem, we use another dummy variable, pre-

\footnotetext{
${ }^{14}$ The estimation results with the latter definition are available upon request.

${ }^{15}$ We treat Shinkin banks, a cooperative financial institution, as a type of commercial bank.
} 
IPO loan $\&$ bank-VC affiliation equal to one if an IPO company receives an investment from either a bank, or a bank-affiliated $\mathrm{VC}$, and has a positive borrowing balance at the end of the last accounting period before the IPO, and zero otherwise. We use this dummy variable as the primary measure of a pre-IPO banking relationship because a loan is more likely to come from a bank if a bank-affiliated investor is a shareholder, despite the possibility that they belong to different financial groups. ${ }^{16}$ We also use the ratio of outstanding loans over total assets at the end of the last accounting period before the IPO, termed pre-IPO loan/asset.

VC-underwriter affiliation dummy variable. To identify the affiliation between a VC and a lead underwriter for an IPO company, we construct a dummy variable Lead arranger-VC affiliation equal to one if another type of $\mathrm{VC}$ or investor that invested in a company before IPO (hereafter, we include these as "VCs") is affiliated with a lead underwriter of the IPO. We assume that a VC is affiliated with an underwriter (i) if the underwriter holds more than $20 \%$ of the VC's shares, or vise versa, (ii) if a certain company holds $20 \%$ of the shares of both the VC and the underwriter, (iii) if the VC holds more than $20 \%$ of a company that holds more than $20 \%$ of the underwriter, or (iv) if the underwriter holds more than $20 \%$ of a company that holds more than $20 \%$ of the VC (see Figure 1). We collected the affiliation information from the list of affiliated companies in section 1-1-4 of each underwriter's or investor's annual financial statement: the state of affiliated companies, to identify the affiliation and the period of affiliation. We suppose that the underwriter can share proprietary information about an IPO firm with its pre-IPO investors if they are affiliated in this way.

\subsection{Descriptive Statistics}

The sample mean of initial returns is $86.9 \%$. Table 1 and Figure 2 show the annual average of the initial returns and the number of IPOs in our sample, which demonstrates a positive correlation between the initial return and the number of IPOs. Both increased and maintained the higher

\footnotetext{
${ }^{16} \mathrm{~A}$ bank can belong to a financial group different from the one to which a bank-affiliated VC belongs. For example, if a regional bank without a VC subsidiary finds that one of its borrowers plans to go public in the near future, it is likely that the bank introduces the firm to another bank's VC subsidiary. In this case, it is still less plausible that the entire pre-IPO borrowing comes from non-bank entities.
} 
(i)

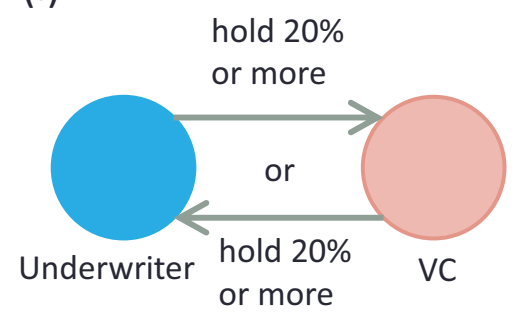

(iii)

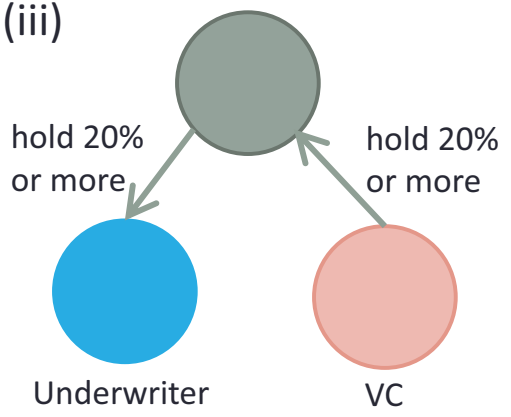

(ii)



(iv)

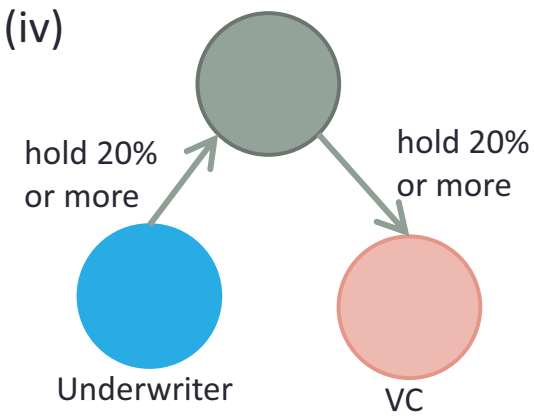

Figure 1: Definition of VC-underwriter affiliation

level until 2006, though they decreased precipitously after the crash of the JASDAQ market after the prosecution of a charismatic representative director of an internet-related venture business for earnings manipulation and other illegal financial operations. The number of IPOs decreased further for several years after the 2008 global financial crisis, but gradually recovered in 2012 and 2013.

Table 2 reports the average initial return by industry, and shows that it tends to be lower for companies in traditional and less innovative sectors such as non-high-tech manufacturing and retail. However, the linear regression of the initial returns on these industry dummies does not show any statistically significant coefficients (Table 3). In contrast, the IPO year effect is far more significant. According to this feature, we fully control for the IPO-year fixed effect while we partially control for the industry effect.

Table 2 also shows the IPO firms' industry composition with banking relationships and those 


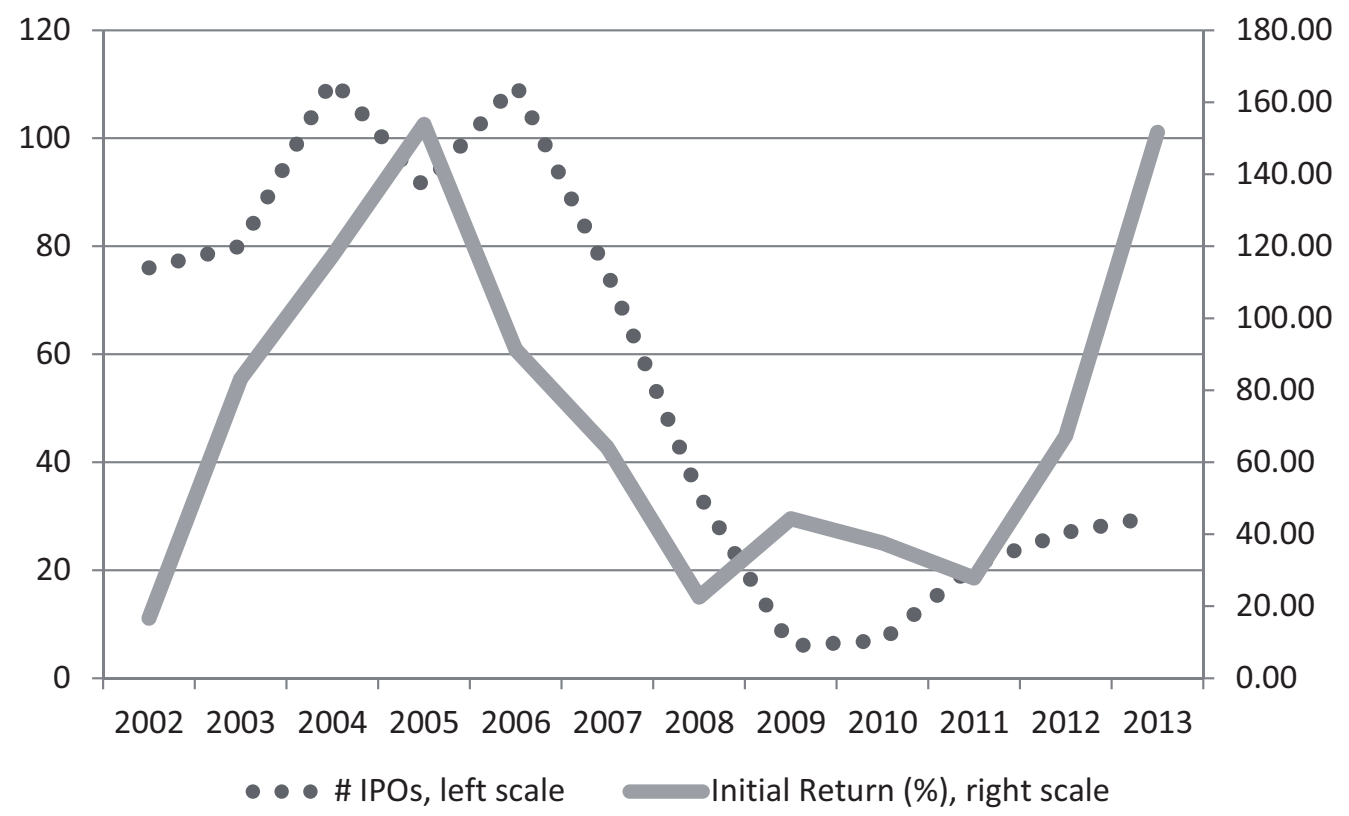

Figure 2: Number of IPOs and Average Initial Return

without. The last column shows the ratio of those with a banking relationship in each sector. Clearly, the ratio is considerably lower in the technology sector (48.7\%) and non-technology services (52.9\%) sectors. This point is consistent with Andrieu and Groh (2012)'s prediction. Those firms in sectors that do not require significant amounts of external funds and are more dependent on venture capitalists' advice tend to choose independent VC backing over bankaffiliated VCs.

\subsection{Univariate Test}

Table 4 shows the univariate test for hypotheses 1 and 2 without controlling for covariates. Row (i) shows the t-test of the difference in means of initial returns and the Wilcoxon test of the difference in medians between firms that received investments from a commercial bank and/or its affiliated VC and others. The mean and median initial returns in the former group are 
lower than those in the latter by $31.1 \%$, and $31.0 \%$, respectively. The difference in means and medians are statistically significant at the $1 \%$ level. Row (ii) shows the results of the tests of the difference in means and medians between firms with a loan at the end of the last accounting period before the IPO and the others. The mean and median initial returns in the former group are lower than those in the latter by $43.1 \%$, and both differences are statistically significant at the $1 \%$ level. The difference between firms with both a loan and a bank or its affiliated VC investment and others is also highly significant (row (iii)). These results indicate the possibility that investors in the IPO market perceive a pre-IPO banking relationship as a signal of low risk.

Row (iv) shows the results of the differences in means and medians between firms whose underwriter is affiliated with one of its pre-IPO VC investors and others. The test of the difference in means does not reject the null hypothesis of no difference, whereas the test of the median indicates a statistically significant difference. However, the differences of means and medians are by far smaller than those in Rows (i)-(iii), at $9.8 \%$ and $24.5 \%$, respectively.

Table 5 presents a comparison of the negative impact of a pre-IPO banking relationship to underpricing in our dataset with the U.S. dataset used in Gonzalez and James (2007). Following Gonzalez and James (2007), we classify sample firms into four categories, based on whether they are in the technology sector and whether they have pre-IPO banking relationships. The mean and median of the IPO underpricing are similar in both datasets for firms with banking relationships both in the technology and non-technology sectors. Both datasets show a large negative impact of the banking relationship on the mean and median of underpricing. A notable difference between these datasets is that the banking relationship has a more significant impact in the technology sector in Japan than in the U.S. This tendency reflects the significant presence of reputable independent VCs in the U.S. Another difference is that the ratio of firms with banking relationships is larger in the technology sector in the U.S., whereas it is larger in the non-technology sector in Japan. The existence of technology-oriented boutique investment banks in the U.S., as is mentioned in Gonzalez and James (2007), and the lack of such institutions in Japan can explain this difference. 


\subsection{Multivariate Test}

To test hypotheses 1 and 2 after controlling for the observable covariates for the initial return, we regress the initial return on a measure of the pre-IPO banking relationships and the VCunderwriter affiliation dummy, together with control variables using the following equation.

$$
\text { initial return }{ }_{i}=\beta_{0}+\beta_{1} \cdot \text { pre-IPO bank relationship } i+\beta_{2}^{\prime} x_{i}+y_{t}+\epsilon_{i},
$$

where $i$ is the index of IPO firms, $\beta$ 's are the coefficients to be estimated, $x_{i}$ is the vector of control variables, $y_{t}$ is the fixed effect of the IPO year $t$, and $\epsilon_{i}$ is the error term with mean zero. The standard errors are estimated by the IPO-year cluster robust estimator. We drop the outliers whose initial return is in the top or the bottom $1 \%$ before the regression analysis.

\subsubsection{Choice of Control Variables}

The existing literature suggests that we must control for the extent of uncertainty, the growth potential, and the leverage of each IPO company. We follow the traditional method (e.g., James and Wier, 1990; Schenone, 2004; Gonzalez and James, 2007) in choosing proxies for these factors. Namely, we use firm age as of the IPO date, the size of the issuer measured by total sales or total funds raised via IPO. We use the ratio of EBITDA over total sales, and the high-tech industry dummy variable (Loughran and Ritter, 2004) as proxies for the growth potential of an issuer. Leverage, defined by the ratio of total liabilities over total assets, is introduced to address the possibility that trade credits, as well as bank loans, may signal low risk.

The lead underwriter's reputation is also a factor that significantly influences underpricing (Beaty and Ritter, 1986; Carter and Manaster, 1990; Carter et al., 1998). We include the lead arranger's share of IPO amounts in each calendar year to control for this factor. ${ }^{17}$ In addition, we include the market index rate of return; the JASDAQ index, in the 40 trading days before an IPO, to address the possibility that the insufficient price revision by an underwriter in the process of book building can have a significant impact on underpricing (Kutsuna et al., 2007). To address the potential influence of the length of the period between the date the offer price

\footnotetext{
${ }^{17}$ We use the largest share if multiple institutions serve as lead underwriters. In the share calculations, we do not count the IPOs without new stock issues because of the lack of share information in these IPOs.
} 
is announced and the IPO date, which is considerably longer in Japan (about 10 days) than in the U.S. (about 1 day), we include the JASDAQ rate of return from the date the offer price is announced to the date of the first trades in the market. We also include the characteristics of the lead VC, such as capital size and age to control for the VC's reputation or the skills in some specifications, following Krishnan et al. (2011)'s findings.

\subsubsection{Description of Independent Variables}

Table 6 lists the exact definitions for the variables used in the regression analysis. Panel (a) in Table 7 shows the descriptive statistics of the key variables and control variables. The table shows that about $55 \%$ of the firms in our dataset have received an investments from a VC that is affiliated with their lead underwriter, $75 \%$ have received an investment from a VC that is affiliated with a commercial bank, and $40 \%$ have received an investment from a VC that is affiliated with a regional bank, including cooperative financial institutions. Additionally, $60 \%$ of the IPO firms have a positive loan balance from banks or other entities at the end of the accounting year before their IPO and have received an investment from a bank or a bankaffiliated VC. The ratio of total borrowing over total assets is $20.7 \%$ on average. Firm age at IPO is on average 16.3 years old, which is much older than the sample mean of 9.7 years in the U.S. (Gonzalez and James, 2007). The ratio of EBITDA over total sales in the last financial statement before IPO is $-93.7 \%$ on average. This number is much lower than the $-44.2 \%$ in Gonzalez and James (2007)'s dataset due to an outlier. The median is about 11.5\%. The mean sales of IPO firms is some 7.5 billion JPY, which is equivalent to about 75 million USD at a rate of 100 JPY per USD. The mean sales of the U.S. IPO firms is 116 million USD in Gonzalez and James (2007). The sales of average IPO firms is greater in the U.S. than in Japan by a factor of approximately 1.5 .

Panel (b) presents the descriptive statistics of sample firms without a pre-IPO banking relationship, which is defined by the existence of a positive amount of borrowing and an investment by a bank or a bank-affiliated VC. Panel (c) presents those of sample firms with a pre-IPO banking relationship. The asterisks in Panel (c) indicate the statistically significant difference 
between the means of these subsamples. Not surprisingly, the ratio of the pre-IPO loans over total assets and the leverage before IPO are larger in the latter subsample, and the difference is statistically significant at the $1 \%$ level. Firms with a banking relationship are older and larger in terms of sales, and these differences are statistically significant at the $1 \%$ level. The panels also indicate that those with a higher ratio of tangible assets over total assets (tangibility at the end of the accounting year two years before IPO) and those outside a metropolitan area such as the prefectures of Tokyo, Osaka, and Aichi (Nagoya) more often have a pre-IPO banking relationship. Firms with higher tangibility are more likely to have a banking relationship since these tangible assets effectively serve as collateral for bank loans. It is difficult to find independent VCs or other types of non-bank financiers in a rural area, where regional banks or cooperative institutions are dominant. The effect of the location of an IPO firm on banking relationships is a reasonable finding given the importance of physical distance in collecting and using the soft information about start-up firms (Liberti and Mian, 2009). These findings suggest that tangibility and the metropolitan dummy variable are natural candidates for instrumental variables to estimate a system of equations where the choice of banking relationship is treated as an endogenous variable.

\subsection{Results of Multivariate Regressions}

\subsubsection{Certification effect of the pre-IPO banking relationship}

Table 9 presents the baseline results of the estimation by the IPO-year fixed-effect model with the IPO-year clustered standard error. Column (1) shows the results when the bank-VC affiliation dummy is used as a measure of the pre-IPO relationship. The estimated coefficient is negative and statistically significant at the $5 \%$ level. Column (2) shows the results when the pre-IPO loan dummy is applied. The estimated coefficient is again negative and significant at the $5 \%$ level. The estimated coefficient is about $-14 \%$, i.e., the pre-IPO lending relationship diminishes the IPO underpricing by about 14 percentage points. These coefficients do not change significantly when we introduce both of these pre-IPO banking relationship measures into the independent variables, $-12 \%$ for bank-affiliated VCs, and -13\% for pre-IPO bank loans (column (3)). Column 
(4) shows the results when we use the pre-IPO loan \& bank-VC affiliation dummy. The estimated coefficient is negative and highly statistically significant at the $1 \%$ level. The estimated coefficient is $-21 \%$, and the impact is economically significant, as the sample mean and median of the initial returns are $87 \%$ and $57 \%$, respectively. When we use the ratio of loans over total assets at the end of the accounting period before IPO in place of the pre-IPO loan dummy, we find a positive but insignificant coefficient (column (5)). This result is consistent with James and Wier (1990)'s prediction that obtaining a bank loan is a more important signal than the amount of the bank loan. It is also consistent with Puri (1999)'s prediction that larger stakes held by underwriters render investors reluctant to purchase these securities out of concern about conflicts of interest.

The existing literature provides a theory and evidence that smaller banks are more competent in producing information about the creditworthiness of small and medium-sized companies (e.g., Stein, 2002; Berger et al., 2005; Uchida et al., 2008). In contrast, Gonzalez and James (2007) show that the mean IPO underpricing of IPO firms that obtain a loan from a boutique bank is significantly higher than that of those from a large bank. They argue that this is due to the characteristics of boutique bank borrowers; smaller in size and less profitable. To test the bank-size effect in our sample, we introduced an additional dummy variable equal to one if a firm receives an investment from a $\mathrm{VC}$ that is affiliated with a regional bank or a cooperative financial institution and it has a loan outstanding at the end of the last accounting period before its IPO. Column (6) shows the results of this regression. The coefficient of the pre-IPO loan and regional-bank-affiliated VC is negative but insignificant. Thus, in our sample, the size of the bank does not impact the degree of underpricing.

Table 10 reports the results of the pre-IPO year fixed-effect model including the VC characteristic variables; the logarithm of the capital of the lead VC and that of the age of the lead VC. These additional variables are collected from the JVR database. The estimated coefficients of the measures of the pre-IPO banking relationship are similar to those in the previous table, despite the substantial reduction of the sample size. The statistical significance is maintained for the coefficient of the dummy variable, Pre-IPO loan \& bank-VC affiliation. These results imply that a pre-IPO lending relationship and a bank-affiliated VC relationship in tandem have 
a certification effect in terms of lowering IPO firm risk.

The estimated coefficients of the control variables are similar in all specifications in Tables 8 and 9. Firm age has a negative and significant impact on the initial return, in line with previous studies. The ratio of EBITDA over total sales in the last accounting period before IPO has a positive and significant coefficient, indicating that this profitability index possibly signals the IPO firm's growth potential. Firms with more growth potential anticipate future equity offerings, and need to take care of their reputation as an issuer in consideration of investors (Allen and Faulhaber, 1989). Consistent with previous studies, the logarithm of sales, which represents the size of a firm, has a negative and significant coefficient, perhaps since larger firms are perceived to be safer. The coefficients of the JASDAQ after offer price, JASDAQ run-up, and boom are positive and significant, also consistent with earlier studies (e.g., Gonzalez and James, 2007; Kutsuna et al., 2007), and suggesting that the offer price revisions during the book building process are often insufficient, especially during stock market booms, possibly because of the anchoring bias on the side of underwriters. The coefficient of the lead arranger's reputation, as measured by its share in the IPO underwriting market each year, is not statistically significant. This result is consistent with that from Beckman et al. (2001) using a Japanese dataset from the 1990s.

\subsubsection{Information revelation and conflicts of interest}

We test hypothesis 2 , the information revelation hypothesis, by introducing the dummy variable lead-arranger VC affiliation equal to 1 if a VC that invested in an IPO firm is affiliated with a lead underwriter of the IPO, into the following regression model.

$$
\text { initial return }{ }_{i}=\beta_{0}+\beta_{1} \cdot \text { lead-arranger } \mathrm{VC} \text { affiliation }{ }_{i}+\beta_{2}^{\prime} x_{i}+y_{t}+\epsilon_{i}
$$

where $i$ is the index of IPO firms, $\beta$ s are the coefficients to be estimated, $x_{i}$ is the vector of control variables, $y_{t}$ is the IPO-year fixed effect, and $\epsilon_{i}$ is the error term with mean zero. The standard errors are estimated by the IPO-year cluster robust estimator. We drop the outliers whose initial return is in the top or the bottom $1 \%$ before the regression analysis. 
Table 11 reports the baseline regression results using this dummy variable. The coefficient of the lead arranger-VC affiliation is positive and statistically insignificant in all specifications in the table. The estimated coefficient of the dummy variable, pre-IPO loan \& bank-VC affiliation, is intact with the introduction of the new dummy variable (column (2)).

Schenone (2004) finds that the IPO underpricing of a firm with a pre-IPO lending relationship with a bank that could serve as an underwriter in an IPO but did not do so is significantly smaller than that of other firms. To conduct a similar test, we use a dummy variable, could equal to one if a firm has a pre-IPO loan and obtains an investment by a VC affiliated with a large bank that has an investment banking subsidiary that can serve as an underwriter in IPO, or a VC affiliated with a security company, which are the major providers of investment banking in Japan. We also introduce another dummy variable, did equal to one if could is equal to one and the lead arranger-affiliated VC is equal to one. The estimated coefficient of could is negative and similar in magnitude to the results obtained by Schenone (2004), but marginally statistically significant. The estimated coefficient of did is also insignificant in all estimations. This result barely changes even if we introduce the characteristics lead VC characteristics (Table 12).

These results suggest that the information revelation hypothesis is not supported by the Japanese dataset, in contrast with the supportive result in the U.S. (e.g., Chemmanur et al., 2010). The result that $d i d$ is not statistically significant also contradicts the rational discounting hypothesis, which is supported by Gompers and Lerner (1999). These results contrasting with the U.S. case can be explained by the difference in the composition of investors participating in the IPO markets in these countries. As presented in Section 2.2, $75 \%$ of the investors in the Japanese IPO market are individual investors, who are supposedly less informed and naive, while $75 \%$ of investors are supposedly informed sophisticated institutional investors in the U.S. Given this composition, investors' concerns about conflicts of interest are less serious, and underpricing is too costly a method to compensate institutional investors for revealing good information in the book building process in Japan. 


\subsubsection{Robustness check: endogeneity of pre-IPO banking relationships}

If an unobservable determinant of the initial return is correlated with the potential for an IPO firm to have a pre-IPO banking relationship, the estimated coefficients of the initial return regression are biased and inconsistent. For example, if the unobservable factor is positively correlated with the uncertainty of firm performance, this unobservable factor increases the initial return, since the initial return is larger for more risky IPO firms, and can be negatively correlated with the potential that the firm obtains bank loans before IPO, since a bank is less willing to extend a loan to riskier firms. The pre-IPO loan dummy is negatively correlated with the error term that includes the unobservable factor in this case. The estimated coefficient of the pre-IPO loan dummy in a single equation regression could be negatively biased if this is the case.

To address this potential problem, we estimate the following simultaneous equation fixedeffect model that treats a measure of a pre-IPO banking relationship as an endogenous variable.

$$
\begin{aligned}
& \text { initial return }{ }_{i}=\beta_{0}+\beta_{1} \cdot \text { pre-IPO bank relationship } i+\beta_{2}^{\prime} x_{i}+y_{t}+\epsilon_{i} \text {, } \\
& \text { pre-IPO bank relationship }{ }_{i}=\gamma_{0}+\gamma_{1}^{\prime} z_{i}+\gamma_{2}^{\prime} x_{i}+y_{t}+\nu_{i} \text {, }
\end{aligned}
$$

where $i$ is the index of IPO firms, $\beta \mathrm{s}$ and $\gamma_{\mathrm{s}}$ are the coefficients to be estimated, $x_{i}$ is the vector of control variables, $z_{i}$ is the vector of the instrumental variables excluded from the initial return equation, $y_{t}$ is the IPO-year fixed effect, and $\epsilon_{i}$ and $\nu_{i}$ are the error terms with mean zero and that are potentially correlated.

We estimated this using a two-stage least square estimation assuming a linear probability model for Eq. 4. To facilitate the identification of the first equation, we need at least an instrumental variable that is excluded from the first equation. We employ the following variables for this purpose: the dummy variable, Metropolitan, which is equal to one if the head office of an IPO firm is located in the metropolitan areas of Tokyo, Osaka, and Aichi (Nagoya) and Tangibility pre-IPO, the ratio of tangible fixed assets over total assets in the second latest accounting period before IPO. Using location information as an excluded instrument variable was originally proposed by Ross (2010). In the context of our dataset, a firm outside the metropolitan area is less likely to find an independent VC since they are concentrated in the 
metropolitan areas, and regional banks or cooperative financial institutions and their affiliates are major financiers outside of metropolitan areas. Furthermore, it is less plausible that the location of a firm's headquarters affects the level of the initial return. Pre-IPO tangibility is an important determinant of the availability of bank loans since it indicates the amount of assets available as collateral. Moreover, it is less plausible that tangibility two years before IPO directly affects the initial returns. Thus, we argue that it is also a strong candidate for the instrumental variable.

Table 13 presents the estimation results with these specifications. The Wald test of the excluded instrumental variables indicates that these variables are sufficiently relevant as determinants of the existence of a pre-IPO banking relationship in all specifications. The Hansen J test (Sagan's test) statistics in the 2SLS estimations indicate that these variables are sufficiently independent of the initial return conditional on the other control variables. Thus, these variables are valid instrumental variables. The estimated coefficients in the banking-relation equation in the first stage show that firms outside the metropolitan areas are more likely to have a pre-IPO relationship with a bank, as expected. The pre-IPO banking relationship is more likely for firms that are larger and older. These findings are consistent with the findings that those backed by an independent VC are younger and small Sun et al. (2013). Firms with more tangible assets and less profits in terms of EBITDA/Sales are also more likely to have a pre-IPO banking relationship. The last point could be because a firm with a smaller cash flow needs more external financing for its working capital and therefore become more dependent on a bank.

The estimated coefficients of the pre-IPO banking-relationship measures are larger than the single equation regression in terms of magnitude. This result suggests that unobservable factors are something either positively correlated with both a pre-IPO banking relationship and the initial return, or negatively correlated with both. The estimated coefficients of the pre-IPO banking relationship measures are far too negative, lower than $-107 \%$, given the mean difference between those with a pre-IPO banking relationship and those without is at most $-43 \%$ (Table $4)$.

This result implies that these relatively under-performing firms are more likely to have a pre- 
IPO banking relationship, and they limit IPO underpricing by making use of the certification effect of the pre-IPO banking relationship. On the other hand, these relatively over-performing firms are less dependent on a bank, and they can limit the underpricing below a certain level without the help of a banking relationship. Thus, the single equation regression could underestimate the impact of the pre-IPO banking relationship. On the whole, we can conclude that this result does not deny the certification effect of pre-IPO banking relationship hypothesis.

\section{Test of Post-IPO Performance.}

\subsection{Measures of Post-IPO Performance.}

The portion of this empirical study examines the difference in the post-IPO performance between those with a pre-IPO banking relationship and those without. To see the difference in credit risk, post-IPO growth, and the idiosyncratic risk of their stocks, we examine the financial performance after IPO: (1) the ratio of EBITDA over Sales, (2) ROA, (3) growth rate of sales from the last accounting period before IPO to three years later and the post-IPO market performance; (4) cumulative abnormal return (CAR), (5) standard deviation of the abnormal return, and (6) the default probability implied by the stock return. ${ }^{18}$. In addition, we examine the differences

\footnotetext{
${ }^{18}$ We estimate the default probability at the end of the second accounting period after IPO for each firm using the KMV model (Bharath and Shumway, 2008). From equations (3.b) and (12) in Merton (1974), which assume corporate value follows geometric Brownian motion with drift, we obtain

$$
\begin{aligned}
f_{t} & =V_{0} \Phi\left(x_{1}\right)-B_{t} \exp (-r t) \Phi\left(x_{1}-\sigma \sqrt{t}\right), \\
\sigma_{y} & =\frac{\sigma V_{0} \Phi\left(x_{1}\right)}{f_{0}},
\end{aligned}
$$

where $x_{1} \equiv\left\{\ln \left(V_{0} / B_{t}\right)+\left(r+\sigma^{2} / 2\right) t\right\} /(\sigma \sqrt{t}), f_{t}$ is the equity value at time $t, V_{0}$ is the corporate value at time 0 , $B_{t}$ is the amount of debt that matures at time $t, r$ is the risk free rate, $\Phi$ is the cumulative distribution function of the standard normal distribution, $\sigma_{y}$ is the volatility of the equity value, and $\sigma$ is the volatility of the corporate value. We set $t$ equal to 250 trading days, or about a year. $B_{t}$ is the debt that matures within 1 year at the end of the second accounting period after IPO. $r$ is the daily yield to maturity of the primary market of a Japanese government bond with a maturity of 10 years at the end of the second accounting period. $\sigma_{y}$ is estimated by the standard deviation of the daily stock returns from 250 trading days before to the date of the end of the second accounting period. We obtain estimates of $V_{0}$, the corporate value at the end of the second accounting period, and $\sigma$, the volatility of the corporate value, by plugging these values into the above equations and solving the nonlinear simultaneous equations with respect to $V_{0}$ and $\sigma$. We scaled down both sides of the first equation by 1000 and scaled up the latter equation by 1000 to achieve a quick convergence in solving the problem. Likewise, we can obtain $V_{1}$ by using the data in the next accounting period. We can estimate the drift term of the process $V_{t} ; \alpha=\left(\ln \left(V_{1}\right)-\ln \left(V_{0}\right)\right) / 250$. The default probability is
}

$$
\operatorname{Prob}\left(\ln V_{t} \leq \ln B_{t}\right)=\Phi\left(-D D_{0}\right), \text { where } D D_{0} \equiv \frac{\ln V_{0}-\ln B_{t}+\left(\alpha-\sigma^{2} / 2\right) t}{\sigma \sqrt{t}} .
$$


in leverage after IPO to see whether a bank strategically creates an early relationship with a firm that is anticipated to have strong demand for bank loans. The detailed definition is listed in Table 14. The market data, such as daily stock returns, including each IPO company's dividends, the daily Fama-French factors, and the risk-free rate (daily yield to maturity of a 10 year Japanese government bond in the primary market) are obtained from the database provided by Financial Data Solutions, Inc. The financial statement data is collected from the Nikkei NEEDS database.

Table 15 lists the descriptive statistics of these variables. Panel (a) shows the statistics for the entire sample; Panel (b) shows the statistics of the subsample of firms without a pre-IPO banking relationship, i.e., pre-IPO loan \& bank-VC affiliation $=0$; and Panel (c) shows the statistics of the subsample of firms with a pre-IPO banking relationship, i.e., pre-IPO loan \& bank-VC affiliation $=1$. The asterisks on the right of the third column in Panel (b) indicates the statistical significance of the t tests of the difference in means between these two subsamples after dropping the top and bottom $1 \%$ of each variable from the full sample. This univariate test clearly shows that firms with a pre-IPO banking relationship are less profitable (ROA) right before and after IPO, and lower CAR and standard deviations of abnormal returns until the third year after IPO. These results are consistent with the hypothesis of the certification effect of pre-IPO banking relationships; those with such a relationship exhibit low risk and low return. However, the estimated probability of default of those with a pre-IPO banking relationship is higher, despite the fact that we control for exiting leverage by setting it at 0.2 for all companies in calculating the default probability. The median test also shows the same pattern (the asterisks on the right of the column showing the median).

Panels (a) and (b) in Figure 3 show the difference in the median profitability in the last accounting period before IPO $(\mathrm{t}=0)$, and the subsequent years. The profitability of those without a pre-IPO banking relationship is significantly higher than others in the first two years, but the difference later diminishes. The pattern of those without a pre-IPO banking relationship is

In the calculation of the last equation, we assume that leverage $B_{t} / V_{0}$ is equal to 0.2 for all companies to control for it. 
similar to that observed in previous empirical studies (e.g., Jain and Kini, 1994; Cai and Wei, 1997). Panel (b) shows the medians of the cumulative abnormal return in the first year after the IPO from the first trading day to the 250th trading day $(\mathrm{t}=1)$, that from the 250 th day to the 500th day $(\mathrm{t}=2)$, and that from the 500th day to the 750th day $(\mathrm{t}=3)$. Panel $(\mathrm{c})$ shows the standard deviations of the daily abnormal return in the same periods. These panels indicate that those with a pre-IPO banking relationship are, indeed, low risk low return, as is predicted by the certification hypothesis.

\subsection{Results of Multivariate Regressions}

We test the hypothesis that those without a pre-IPO banking relationship exhibit high risk high return performance after IPO by regressing these post-IPO performance measures to various factors observable at the time of the IPO, including leverage, firm age, total assets, sales, and the number of employees, in a sector and IPO-year fixed-effect model.

Table 16 reports the estimation result. Columns (1) and (3) in Panel (a) are the result when the dependent variable is the profitability measures in the first accounting period after IPO. The estimated coefficient of Pre-IPO loan \& bank-VC affiliation is negative and statistically significant at the $1 \%$ level. The estimates indicate that those with a pre-IPO banking relationship are less profitable by $2.6 \%$ in EBITDA/sales, and by $1.9 \%$ in ROA. These are economically significant, since their medians are $10.8 \%$ and $8.8 \%$, respectively. This difference is insignificant in the third year after IPO (Columns (2) and (3)).

Columns (5) and (6) in Panel (a) show that the borrowing normalized by asset size of those with a pre-IPO banking relationship are significantly higher. Japanese bank-affiliated VCs choose firms that are expected to maintain their dependence on bank loans after IPO.

Panel (b) of Table 16 shows no significant impact of a pre-IPO banking relationship on the default probability implied by the stock return in the second year after the IPO (column (1)), the CAR in the first and the third year after the IPO (columns (2) and (3)), the idiosyncratic risk in the first and the third years (columns (4) and (5)), and the sales growth from the last accounting period before IPO to the third accounting period after IPO. 
To further investigate post-IPO performance, we estimated the fixed-effect model in Table 16 by treating the pre-IPO banking relationship as an endogenous variable as in Table 13. The excluded instrumental variables are Metropolitan and pre-IPO tangibility. Each row of Table 17 is the result of an endogenous dummy variable model with various dependent variables, and each shows the estimated coefficient of Pre-IPO loan \& bank-VC affiliation and other relevant statistics in each regression. The estimated coefficient of the profitability measures lose statistical significance. The coefficients of loan/asset are still positive and significant, but the Sargan test indicates that some of the excluded instrumental variables have significant correlations with the error terms of the second stage regression and are potentially biased. The pre-IPO banking relationship has a negative and statistically significant correlation with CAR in the third year, and the standard deviation of abnormal returns in the first and third year after IPO. The first two among these indicate that the instrumental variables are valid in terms both of the Wald test and of the Sargan test. Thus, our regression analysis overall supports the hypothesis that those with a pre-IPO banking relationship are more likely to exhibit low risk low return after IPO.

\section{Concluding Remarks}

This study's empirical analyses provide evidence that a pre-IPO banking relationship significantly reduces IPO underpricing, in particular when the relationship is through both loans and investments by the lender's VC subsidiaries by using a new non-US dataset. The results imply that this effect is less likely a result of reductions in the underwriter's necessity to extract information from informed institutional investors in the process of book building, but mainly comes from the reduction of the winner's curse against uninformed investors or the reduction of the IPO firm's signaling incentive, given the fact that most Japanese IPO investors are supposedly uninformed naive individuals. Thus, uninformed investors recognize pre-IPO relationships with banks as a certification for the firm's potential performance. The post-IPO market performance exhibits low risk low return in a manner consistent with the certification hypothesis.

The pre-IPO banking relationship minimizes the financing cost of IPO firms in the form of 
the underpricing, which is often referred to as "money left on the table." Thus, the information produced by banks contributes to economic efficiency in the IPO market. However, the industry portfolio of bank-affiliated VCs is tilted toward the sectors from which banks expect a larger demand for loans in the future, while those sectors in which demand for loans appears weak, such as the service sector, are under-weighted. This finding indicates that the portfolio of bankaffiliated VCs is biased away from a socially optimal portfolio, as pointed out by Hellmann et al. (2008). In the case of Japan, the technology sector is also under-weighted in the portfolio of bank-affiliated VCs. This result can be explained by the lack of technology-oriented boutique banks in Japan, which are important players in the VC market in the U.S. To facilitate socially optimal fund raising for emerging companies, the existence of reputable independent VCs who have no incentive to distort their portfolios and can play a certification role in the IPO market, is indispensable.

\section{References}

Aggarwal, R., N. R. Prabhala, and M. Puri, (2002). "Institutional Allocation in Initical Public Offerings: Empirical Evidence," Journal of Finance 57: 1421-1442.

Allen, F. and G. R. Faulhaber, (1989). "Signaling by Underpricing in the IPO Market," Journal of Financial Economics 23: 303-323.

Andrieu, G. and A. P. Groh, (2012). "Entrepreneurs Financing Choice between Independent and Bank-Affiliated Venture Capital Firms," Journal of Corporate Finance 18: 1143-1167.

Arikawa, Y. and G. Imad'eddine, (2010). "Venture Capital Affiliation with Underwriters and the Underpricing of Initial Public Offerings in Japan," Journal of Economics and Business 62: $502-516$.

Barry, C. and V. Mihov, (2005). "Debt Financing and Initial Public Offerings," . mimeo. Texas Christian University. 
Beaty, R. P. and J. R. Ritter, (1986). "Investment Banking, Reputation, and the Underpricing of Initial Public Offerings," Journal of Financial Economics 15: 213-232.

Beckman, J., J. Garner, B. Marshall, and H. Okamura, (2001). "The Influence of Underwriter Reputation, Keiretsu Affiliation, and Financial Health on the Underpricing of Japanese IPOs," Pacific-Basin Finance Journal 9: 513-534.

Benveniste, L. M. and P. A. Spindt, (1989). "How Investment Bankers Determine the Offer Price and Allocation of New Issues," Journal of Financial Economics 24: 343-361.

Benzoni, L. and C. Schenone, (2010). "Conflict of Interest and Certicification in the U.S. IPO Market," Journal of Financial Intermediation 19: 235-254.

Ber, H., Y. Yafeh, and O. Yosha, (2001). "Conflict of Interest in Universal Banking: Bank Lending, Stock Underwriting, and Fund Management," Journal of Monetary Economics 47: $189-218$.

Berger, A. and G. Udell, (1995). "Relationship Lending and Lines of Credit in Small Business Finance," Journal of Business 30(3) : 351-381.

Berger, A., N. Miller, M. Petersen, R. Rajan, and J. Stein, (2005). "Does Function Follow Organizational Form? Evidence from the Lending Practices of Large and Small Banks," Journal of Financial Economics 76: 237-269.

Bharath, S. T. and T. Shumway, (2008). "Forecasting Default with the Merton Distance to Default Model," Review of Financial Studies 21(3) : 1339-1369.

Bharath, S., S. Dahiya, A. Saunders, and A. Srinivasan, (2011). "Lending Relationships and Loan Contract Terms," Review of Financial Studies 24: 1141-1203.

Cai, J. and K. J. Wei, (1997). "The Investment and Operating Performance of Japanese Initial Public Offerings," Pacific-Basin Finance Journal 5: 389-417. 
Carter, R. and S. Manaster, (1990). "Initial Public Offers and Underwirter Reputation," Journal of Finance 45: 1045-1067.

Carter, R. B., F. H. Dark, and A. K. Singh, (1998). "Underwriter Reputation, Initial Returns, and the Long-Run Performance of IPO Stocks," Journal of Finance 53: 285-311.

Chemmanur, T. J., G. Hu, and J. Huang, (2010). "The Role of Insitutional Investors in Initial Public Offerings," Review of Financial Studies 23: 4496-4540.

Dass, N. and M. Massa, (2011). "The Impact of a Strong Bank-Firm Relationship on the Borrowing Firm," Review of Financial Studies 24: 1204-1260.

Engelen, P.-J. and M. van Essen, (2010). "Underpricing of IPOs: Firm-, issue- and countryspecific characteristics," Journal of Banking and Finance 34: 1958-1969.

Funaoka, K., (2008). "Shinki Koukai Kabushiki No Puraishing Ni Okeru Kikan Toshika No Yakuwari (Role of Institutional Investors in IPO Pricing)," Shoken Keizai Kenkyu 63: 1-27. (in Japanese).

Gompers, P. A. and J. Lerner, (1999). "Conflict of Interest in the Issuance of Public Securities: Evidence from Venture Capital," Journal of Law and Economics 42: 1-28.

Gonzalez, L. and C. James, (2007). "Banks and Bubbles: How Good Are Bankers at Spotting Winners?," Journal of Financial Economics 86: 40-70.

Grinblatt, M. and C. Huang, (1989). "Signaling and the Pricing of New Issues," Journal of Finance 44: 393-420.

Hamao, Y., F. Packer, and J. R. Ritter, (2000). "Institutional Affiliation and the Role of Venture Capital: Evidence from Initial Public Offerings in Japan," Pacific-Basin Financial Journal 8: $529-558$.

Hellmann, T., L. Lindsey, and M. Puri, (2008). "Building Relationship Early: Banks in Venture Capital," Review of Financial Studies 21: 513-541. 
Jain, B. A. and O. Kini, (1994). "The Post-Issue Operating Performance of IPO Firms," Journal of Finance 49(5) : 1699-1726.

James, C., (1987). "Some Evidence on the Uniqueness of Bank Loans," Journal of Financial Economics 19: 217-235.

James, C. and P. Wier, (1990). "Borrowing Relationships, Intermediation, and the Cost of Issuing Public Securities," Journal of Financial Economics 28: 149-171.

Kerins, F., K. Kutsuna, and R. Smith, (2007). "Why Are IPOs Underpriced? Evidence from Japan's Hybrid Auction-Method Offerings," Journal of Financial Economics 85: 637-666.

Kondo, M., K. Yoshiwara, and E. Kuronuma, (2010). “Kin'yu Kikan To Yuka Shoken Kanren Gyomu (Financial Institutions and Activities Related to Securities),” , Chap. Part 4, Chapter 2 Shoji Houmu.

Konishi, M. and K. Suzuki, (2007). "The Benefit of Concurrent Bank Lending and Investing via Bank-Affiliated Venture Capital," Hitotsubashi Journal of Commerce and Management 41.

Koyama, Y., (2012). "Ginko Tou No Shusshi Seigen (Shareholding Restriction for Banks)," , Chap. 16 Kin’yu Zaisei Jijo Kenkyu Kai (Kinzai Institute for Financial Affairs, Inc.).

Krishnan, C. N. V., V. I. Ivanov, R. W. Masulis, and A. K. Singh, (2011). "Venture Capital Reputation, Post-IPO Performance, and Corporate Governance," Journal of Financial and Quantitative Analysis 46(5) : 1295-1333.

Kroszner, R. S. and R. G. Rajan, (1994). "Is the Glass-Steagall Act Justified? A Study of the U.S. Experience with the Universal Banking before 1933," American Economic Review 84: 810-832.

Kutsuna, K., J. K. Smith, and R. L. Smith, (2007). "Banking Relationships and Access to Equity Capital Markets: Evidence from Japan's Main Bank System," Journal of Banking 6 Finance 31: $335-360$. 
Liberti, J. and A. Mian, (2009). "Estimating the Effect of Hierarchies on Information Use," Review of Financial Studies 22: 4057-4090.

Ljungqvist, A., (2008). "IPO Underpricing," in Eckbo, B. E. (Ed.), Handbook of Corporate Finance: Empirical Corporate Finance, vol. 1, North-Holland, Chap. 7.

Loughran, T. and J. Ritter, (2004). "Why Has IPO Underpricing Changed over Time?," Financial Management 33: 5-37.

Lummer, S. L. and J. J. MacConnell, (1989). "Further Evidence on the Bank Lending Process and the Capital-Market Response to Bank Loan Agreements," Journal of Financial Economics 25: $99-122$.

Merton, R. C., (1974). "On the Pricing of Corporate Debt: The Risk Structure of Interest Rates," Journal of Finance 29(2) : 449-470.

Mester, L., L. Nakamura, and M. Renault, (2007). "Transactions Accounts and Loan Monitoring," Review of Financial Studies 20(3) : 529-556.

Norden, L. and M. Weber, (2010). "Credit Line Usage, Checking Account Activity, and Default Risk of Bank Borrowers," Review of Financial Studies 23(10) : 3665-3699.

Petersen, M. and R. Rajan, (1994). "The Benefits of Lending Relationships: Evidence from Small Business Data," Journal of Finance 49(1) : 3-37.

Puri, M., (1996). "Commercial Banks in Investment Banking: Conflict of Interests or Certification Role?," Journal of Financial Economics 40: 373-401.

(1999). "Commercial Banks as Underwriters: Implications for Going Public Process," Journal of Financial Economics 54: 133-163.

Rock, K., (1986). "Why New Issues Are Underpriced," Journal of Financial Economics 15: $187-212$. 
Ross, D., (2010). "The 'Dominant Bank Effect': How High Lender Reputation Affects the Information Content and Terms of Bank Loans," Review of Financial Studies 23: 2730-2756.

Schenone, C., (2004). "The Effect of Banking Relationships on the Firm's IPO Underpricing," Journal of Finance 59(6) : 2903-2958.

Stein, J., (2002). "Information Production and Capital Allocation: Decentralized versus Hierarchical Firms," Journal of Finance 57: 1891-1921.

Sun, Y. and K. Uchida, (2013). "Strategic Investments of Bank-Affiliated Venture Capitalists: Evidence from Japan," . Kyushu University, Mimeo.

Sun, Y., K. Uchida, and M. Matsumoto, (2013). "The Dark Side of Independent Venture Capitalists: Evidence from Japan," Pacific-Basin Finance Journal 24: 279-300.

Uchida, H., G. Udell, and W. Watanabe, (2008). "Bank Size and Lending Relationships," Journal of the Japanese and International Economies 22(2) : 242-267.

Welch, I., (1989). "Seasoned Offerings, Imitation Costs and the Underpricing of Initial Public Offerings," Journal of Finance 47: 695-732. 


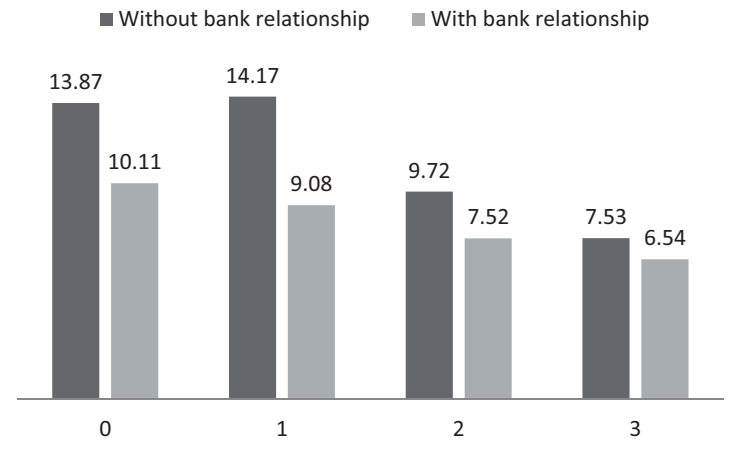

(a) EBITDA/SALES (\%)

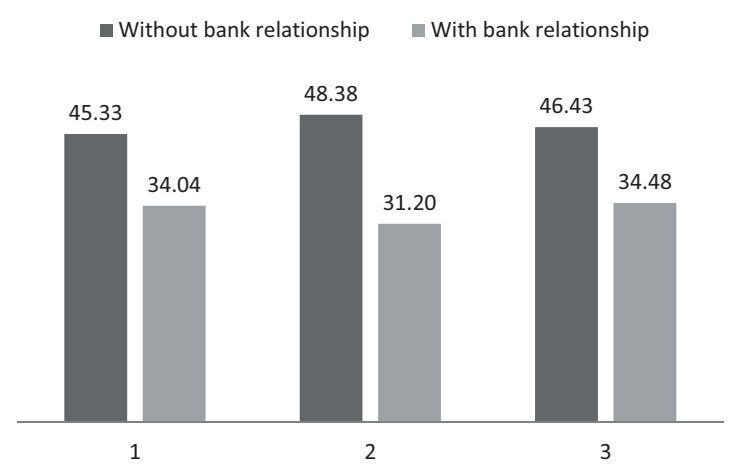

(c) Cumulative Abnormal Return (\%)

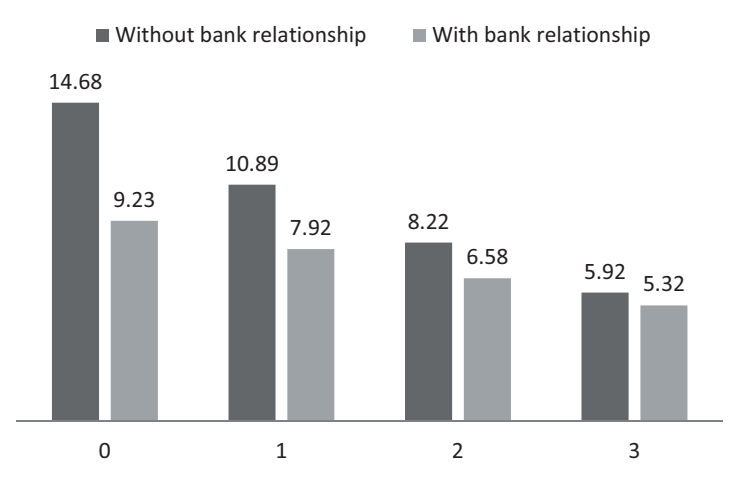

(b) $\mathrm{ROA}(\%)$

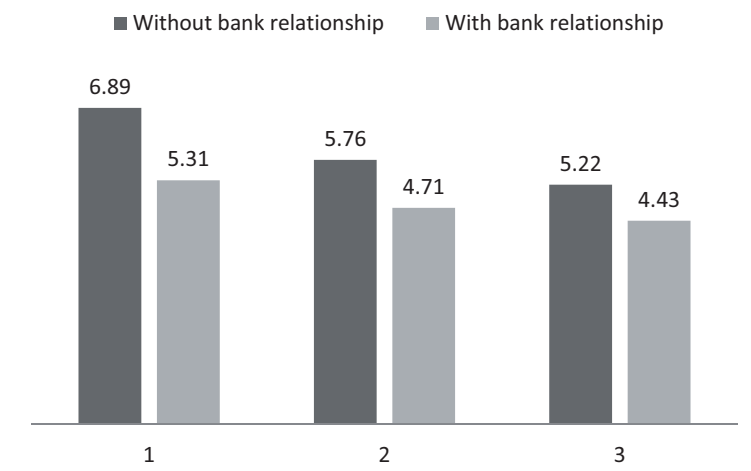

(d) S.D. of Daily Abnormal Return (\%)

Figure 3: Post-IPO performance

(Notes) " 0 " in the horizontal axis indicates the value in the last accounting period ending before IPO. "1" indicates the value in the next period, and so forth. 
Table1. Time Series of initial return

\begin{tabular}{rrrr}
\hline \hline Calendar & \#IPOs & \multicolumn{2}{c}{ Initial Return (\%) } \\
\cline { 3 - 4 } Year & & (mean) & (median) \\
\hline 2002 & 76 & 16.68 & 2.75 \\
2003 & 80 & 83.23 & 58.32 \\
2004 & 111 & 117.34 & 87.50 \\
2005 & 91 & 153.83 & 131.25 \\
2006 & 110 & 91.24 & 56.67 \\
2007 & 75 & 64.03 & 44.14 \\
2008 & 34 & 22.53 & -3.85 \\
2009 & 6 & 44.31 & 47.65 \\
2010 & 7 & 37.58 & 8.00 \\
2011 & 21 & 27.83 & 0.00 \\
2012 & 27 & 67.41 & 47.00 \\
2013 & 30 & 151.67 & 135.25 \\
\hline Total & 668 & 86.88 & 56.09 \\
\hline \hline
\end{tabular}


Table 2. Sector characteristics

\begin{tabular}{|c|c|c|c|c|c|c|}
\hline \multirow[b]{2}{*}{ sectors } & \multicolumn{2}{|c|}{ Initial Return (\%) } & \multicolumn{3}{|c|}{ \#IPO firms with VC } & \\
\hline & mean & s.d. & $\begin{array}{l}1 \text { ) Without bank } \\
\text { relationship }\end{array}$ & $\begin{array}{l}\text { (2) With bank } \\
\text { relationship } \\
\end{array}$ & Total & $\begin{array}{c}\text { Ratio of (2) } \\
\text { over total } \\
\end{array}$ \\
\hline Construction & 80.4 & 139.3 & 3 & 8 & 11 & $72.7 \%$ \\
\hline Technology* & 92.5 & 116.0 & 96 & 91 & 187 & $48.7 \%$ \\
\hline Non-technology mfg. & 61.3 & 116.8 & 14 & 60 & 74 & $81.1 \%$ \\
\hline Real estate & 112.6 & 143.0 & 11 & 36 & 47 & $76.6 \%$ \\
\hline Retail & 69.1 & 80.1 & 17 & 42 & 59 & $71.2 \%$ \\
\hline Non-technology service & 91.5 & 127.6 & 104 & 117 & 221 & $52.9 \%$ \\
\hline Wholesale & 78.9 & 99.2 & 16 & 34 & 50 & $68.0 \%$ \\
\hline Others & 93.3 & 88.5 & 8 & 11 & 19 & $57.9 \%$ \\
\hline Total & 86.9 & 118.2 & 269 & 399 & 668 & $59.7 \%$ \\
\hline
\end{tabular}

* Technology sector includes firms whose NIKKEI industry code is 109081 (major drugs), 109082 (ethical drugs), 123224 (communication equipment), 123225 (electronic components), 123226 (electric industrial controls), 123227 (batteries), 123228 (electric components), 131303 (measuring devices), 265641 (communication services), and those classified as the information technology sector by JVR among those in 271704 (miscellaneous services). Firms are classified into those with bank relationship if they are backed by a bank-affilaited VC and have a positive amount of borrowing before IPO. 
Table 3. Initial return regression on IPO year and sector dummies

Notes. Dependent variable is the initial return. The coefficients are estimated by OLS. The estimated constant term is omitted from the table. Base category is year 2002 and the construction sector. *, **, and ${ }^{* * *}$ indicate that the estimated coefficient is different from zero at a $10 \%, 5 \%$, and $1 \%$ statistical significance level, respectively (two-sided).

\begin{tabular}{lrrc}
\hline \hline & Est.Coef. & S.E. & P-value \\
\hline year2003 & 70.484 & 17.746 & $0.000 * * *$ \\
year2004 & 100.930 & 16.461 & $0.000^{* * *}$ \\
year2005 & 137.868 & 17.184 & $0.000^{* * *}$ \\
year2006 & 75.079 & 16.455 & $0.000^{* * *}$ \\
year2007 & 46.468 & 18.034 & $0.010^{* *}$ \\
year2008 & 7.282 & 22.788 & 0.749 \\
year2009 & 28.991 & 46.800 & 0.536 \\
year2010 & 16.750 & 43.558 & 0.701 \\
year2011 & 3.447 & 27.403 & 0.900 \\
year2012 & 48.448 & 24.749 & $0.051 *$ \\
year2013 & 138.072 & 23.948 & $0.000 * * *$ \\
High-tech & 25.505 & 34.407 & 0.459 \\
Non-technology mfg. & -15.104 & 35.782 & 0.673 \\
Others & 18.790 & 41.961 & 0.654 \\
Real estate & 38.322 & 37.133 & 0.302 \\
Retail & -5.149 & 36.290 & 0.887 \\
Non-technology service & 18.498 & 34.225 & 0.589 \\
Wholesale & 1.453 & 36.815 & 0.969 \\
\hline Adj-R-sq & 0.133 & & \\
N & 668 & & \\
\hline \hline
\end{tabular}


Table 4. Pre-IPO bank relationship and initial return

Note. *, **, and ** indicate that the means or medians of two groups are different at a $10 \%, 5 \%$, and $1 \%$ statistical significance level, respectively (one-sided).

\begin{tabular}{|c|c|c|c|}
\hline \multicolumn{4}{|c|}{ "Initial Return } \\
\hline & $\mathrm{N}$ & Mean & Median \\
\hline \multicolumn{4}{|c|}{ (i) Pre-IPO investment by bank or bank-affiliated VC } \\
\hline Yes & 502 & 79.16 & 47.31 \\
\hline No & 166 & 110.23 & 78.29 \\
\hline $\mathrm{t}$ test/median test & & $2.952 * * *$ & $7.215 * * *$ \\
\hline p-value & & 0.007 & 0.007 \\
\hline \multicolumn{4}{|c|}{ (ii) Positive loan outstanding at the IPO } \\
\hline Yes & 502 & 76.17 & 43.39 \\
\hline No & 166 & 119.29 & 86.51 \\
\hline $\mathrm{t}$ test/median test & & $4.122 * * *$ & $15.519 * * *$ \\
\hline $\mathrm{p}$-value & & 0.000 & 0.000 \\
\hline \multicolumn{4}{|c|}{ (iii) Intersection of (i) and (ii) } \\
\hline Yes & 399 & 70.02 & 40.00 \\
\hline No & 269 & 111.90 & 80.00 \\
\hline $\mathrm{t}$ test/median test & & $4.556 * * *$ & $16.188 * * *$ \\
\hline p-value & & 0.000 & 0.000 \\
\hline \multicolumn{4}{|c|}{ (iv) VC is affilaited with a lead underwriter } \\
\hline Yes & 366 & 81.43 & 42.21 \\
\hline No & 302 & 91.25 & 66.67 \\
\hline $\mathrm{t}$ test/median test & & 1.224 & $6.189 * *$ \\
\hline p-value & & 0.111 & 0.013 \\
\hline
\end{tabular}


Table 5. Comparison of initial returns between Japan and US.

(a) JAPAN (2002-2013; initial return \%)

\begin{tabular}{llrrrrr}
\hline \hline & & $\mathrm{N}$ & Mean & Med & Min & Max \\
\hline Technology & With bank relation & 91 & 53.52 & 35.00 & -46.20 & 333.33 \\
& Without bank relation & 96 & 129.48 & 100.65 & -37.86 & 726.92 \\
Non-technology & With bank relation & 308 & 74.89 & 40.78 & -56.86 & 863.64 \\
& Without bank relation & 173 & 102.14 & 69.00 & -99.96 & 776.92 \\
\hline \hline
\end{tabular}

(b) U. S. (1996-2000; Gonzalez and James, 2007; initial return \%)

\begin{tabular}{llrrrrr}
\hline \hline & & $\mathrm{N}$ & Mean & Med & Min & Max \\
\hline Technology & With bank relation & 395 & 62.38 & 28.76 & -32.81 & 697.50 \\
& Without bank relation & 134 & 75.61 & 43.35 & -24.45 & 605.56 \\
\hline Non-technology & With bank relation & 86 & 80.61 & 44.70 & 7.00 & 1734.00 \\
& Without bank relation & 66 & 225.85 & 56.00 & 5.30 & 212.50 \\
\hline \hline
\end{tabular}

Notes

1. Technology sector in Japan includes firms whose NIKKEI industry code is 109081 (major drugs), 109082 (ethical drugs), 123224 (communication equipment), 123225 (electronic components), 123226 (electric industrial controls), 123227 (batteries), 123228 (electric components), 131303 (measuring devices), 265641 (communication services), and those classified as the information technology sector by JVR among those in 271704 (miscellaneous services). Those with both a pre-IPO borrowing and a pre-IPO investment by a bank-affiliated VC are classifed as those with bank relations in the Japanese dataset.

2. The data in the U.S. is excerpted from Table 1 on pages 46-47 in James and Gonzalez (2007). The definition of the technology sector follows Loughran and Ritter (2004). Those with a pre-IPO bank loan outstanding are classfied as those with bank relations. 
Table 6. Definition of variables in the regression analysis

\begin{tabular}{|c|c|}
\hline$\overline{\text { Variable }}$ & $\begin{array}{c}\text { Definition } \\
\end{array}$ \\
\hline Initial return & $\begin{array}{l}\text { Percentage return from the offer price to the closing price of the first trading day in the } \\
\text { stock exchange (\%). }\end{array}$ \\
\hline Lead arranger-VC affiliation & $\begin{array}{l}\text { A dummy variable, which is equal to } 1 \text { if a lead underwriter in IPO is affiliated with a } \\
\text { VC that has invested in the firm or zero otherwise. }\end{array}$ \\
\hline Bank-VC affiliation & $\begin{array}{l}\text { A dummy variable, which is equal to } 1 \text { if a firm recieves pre-IPO investment from a } \\
\text { bank, including cooperative institutions or its affiliated VCs or zero otherwise. }\end{array}$ \\
\hline Regional bank-VC affiliation & $\begin{array}{l}\text { A dummy variable, which is equal to } 1 \text { if a firm recieves pre-IPO investment from a } \\
\text { regional bank including cooperative institutions or its affiliated VCs or zero otherwise. }\end{array}$ \\
\hline Pre-IPO loan & $\begin{array}{l}\text { A dummy variable, which is equal to } 1 \text { if a firm has positive borrowing at the end of } \\
\text { the accounting year before IPO or zero otherwise. }\end{array}$ \\
\hline $\begin{array}{l}\text { Pre-IPO loan \& bank-VC } \\
\text { affiliation }\end{array}$ & Bank-VC affiliation * Pre-IPO loan. \\
\hline Pre-IPO loan / asset & Ratio of total borrowing over total assets at the end of the accounting year before IPO. \\
\hline Firm age at IPO & Firm age since the start-up as of IPO (years). \\
\hline Funding amount & Amount raised by IPO (million JPY). \\
\hline EBITDA / sales at IPO & EBITDA over total sales in the last accounting year before IPO (\%). \\
\hline Sales at IPO & Total sales in the last accounting year before IPO (million JPY). \\
\hline Leverage at IPO & $\begin{array}{l}\text { Total liability over the total book value of equity at the end of the accounting year } \\
\text { before IPO. }\end{array}$ \\
\hline Lead arranger's reputation & $\begin{array}{l}\text { A lead arranger's IPO market shares in terms of amounts in the year of IPO (\%). If } \\
\text { multiple underwriters serve as lead arrangers, the largest share is used. }\end{array}$ \\
\hline JASDAQ after offer price & $\begin{array}{l}\text { JASDAQ index rate of return from the date of the announcement of offer price to the } \\
\text { closing of the first trading date (\%). }\end{array}$ \\
\hline JASDAQ run-up (40 days) & JASDAQ index rate of return in 40 trading days before IPO (\%). \\
\hline Boom & $\begin{array}{l}\text { A dummy variable, which is equal to } 1 \text { if the IPO is earlier than } 2007 \text { or zero } \\
\text { otherwise. }\end{array}$ \\
\hline Metropolitan & $\begin{array}{l}\text { A dummy variable, which is equal to } 1 \text { if the head office of the IPO firm is located in } \\
\text { the prefecture of Tokyo, Osaka, or Aichi (Nagoya) or zero otherwise. }\end{array}$ \\
\hline Tangibility pre-IPO & $\begin{array}{l}\text { Ratio of tangible assets over total assets at the end of the accounting year two years } \\
\text { before IPO. }\end{array}$ \\
\hline Lead VC capital & The stated capital of the lead VC (mil. JPY). \\
\hline Lead VC age & Years from the start of the lead VC to the IPO date (years). \\
\hline High-tech & $\begin{array}{l}\text { A dummy variable, which is equal to one if the firm is in the technology sector or zero } \\
\text { otherwise. The technology sector is defined in the note of Table } 2 \text {. }\end{array}$ \\
\hline
\end{tabular}


Table 7. Descriptive statistics of variables

\begin{tabular}{|c|c|c|c|c|c|c|}
\hline variable & $\mathrm{N}$ & Mean & s.d. & Min & Med & $\overline{\mathrm{Max}}$ \\
\hline \multicolumn{7}{|l|}{ (a) Full sample } \\
\hline Initial return (\%) & 668 & 86.88 & 118.23 & -99.96 & 56.09 & 863.64 \\
\hline Lead arranger-VC affiliation $(0,1)$ & 668 & 0.548 & 0.498 & & & \\
\hline Bank-VC affiliation $(0,1)$ & 668 & 0.751 & 0.432 & & & \\
\hline Regional bank-VC affiliation $(0,1)$ & 668 & 0.397 & 0.490 & & & \\
\hline Pre-IPO loan $(0,1)$ & 668 & 0.751 & 0.432 & & & \\
\hline Pre-IPO loan \& bank-VC affiliation $(0,1)$ & 668 & 0.597 & 0.491 & & & \\
\hline Pre-IPO loan / asset & 668 & 0.207 & 0.210 & 0 & 0.144 & 0.911 \\
\hline Firm age at IPO (years) & 668 & 16.328 & 13.368 & 1.734 & 11.260 & 71.479 \\
\hline Funding amount (million JPY) & 668 & 1330 & 4940 & 36.8 & 519 & 92000 \\
\hline EBITDA / sales at IPO (\%) & 668 & -93.668 & 2509.321 & -64800.000 & 11.481 & 63.235 \\
\hline Sales at IPO (million JPY) & 668 & 7469.172 & 11296.530 & 1 & 3755 & 127628 \\
\hline Leverage at IPO & 668 & 3.269 & 3.179 & -11.500 & 2.290 & 36.309 \\
\hline Lead arranger's reputation (\%) & 668 & 21.360 & 12.085 & 0.024 & 21.719 & 50.952 \\
\hline JASDAQ after offer price (\%) & 668 & 0.754 & 8.077 & -21.030 & 0.142 & 60.881 \\
\hline JASDAQ run-up (40 days) (\%) & 668 & 0.650 & 10.019 & -27.468 & 0.409 & 39.288 \\
\hline Metropolitan $(0,1)$ & 668 & 0.689 & 0.463 & & & \\
\hline Tangibility pre-IPO & 667 & 0.164 & 0.189 & 0 & 0.072 & 0.921 \\
\hline lead VC capital (million JPY) & 492 & 9358.774 & 14025.690 & 2 & 2950 & 100000 \\
\hline lead VC age at IPO (years) & 469 & 21.281 & 12.258 & 0.132 & 21.858 & 47.334 \\
\hline \multicolumn{7}{|c|}{ (b) Firms without a bank relationship (pre-IPO loan \& bank-VC affiliation $=0$ ) } \\
\hline Initial return (\%) & 269 & $111.898^{* * *}$ & 132.018 & -99.959 & 80.000 & 776.923 \\
\hline Lead arranger-VC affiliation $(0,1)$ & 269 & $0.383^{* * *}$ & 0.487 & & & \\
\hline Pre-IPO loan / asset & 269 & $0.103^{* * *}$ & 0.174 & 0 & 0 & 0.911 \\
\hline Firm age at IPO (years) & 269 & $11.980^{* * *}$ & 9.561 & 1.849 & 8.589 & 49.490 \\
\hline Funding amount (million JPY) & 269 & 1610 & 6810 & 36.8 & 521 & 92000 \\
\hline EBITDA / sales at IPO (\%) & 269 & 4.982 & 87.919 & -916.105 & 13.666 & 63.235 \\
\hline Sales at IPO (million JPY) & 269 & $4544.498^{* * *}$ & 7411.764 & 37 & 2433 & 61889 \\
\hline Leverage at IPO & 269 & $2.572^{* * *}$ & 2.842 & 1 & 1.703 & 29.414 \\
\hline Lead arranger's reputation (\%) & 269 & 21.540 & 13.041 & 0.024 & 21.719 & 50.952 \\
\hline JASDAQ after offer price (\%) & 269 & 0.195 & 6.341 & -17.220 & 0.094 & 36.437 \\
\hline JASDAQ runup (40 days) (\%) & 269 & 0.272 & 9.070 & -23.261 & 0.425 & 30.473 \\
\hline Metropolitan $(0,1)$ & 269 & $0.818^{* * *}$ & 0.387 & & & \\
\hline Tangibility pre-IPO & 268 & $0.085^{* * *}$ & 0.125 & 0 & 0.037 & 0.714 \\
\hline lead VC capital (million JPY) & 176 & 9761.500 & 14779.940 & 2 & 2275 & 100000 \\
\hline lead VC age at IPO (years) & 170 & 19.993 & 13.244 & 0.959 & 19.716 & 44.268 \\
\hline \multicolumn{7}{|c|}{ (c) Firms with bank relationship (pre-IPO loan \& bank-VC affiliation =1) } \\
\hline Initial return (\%) & 399 & 70.018 & 104.801 & -56.857 & 40.000 & 863.636 \\
\hline Lead arranger-VC affiliation $(0,1)$ & 399 & 0.659 & 0.475 & & & \\
\hline Pre-IPO loan / asset & 399 & 0.277 & 0.203 & 0.0005423 & 0.243918 & 0.861 \\
\hline Firm age at IPO (years) & 399 & 19.259 & 14.716 & 1.734 & 13.904 & 71.479 \\
\hline Funding amount (million JPY) & 399 & 1150 & 3110 & 48.1 & 512 & 46500 \\
\hline EBITDA / sales at IPO (\%) & 399 & -160.177 & 3245.963 & -64800.000 & 10.272 & 54.096 \\
\hline Sales at IPO (million JPY) & 399 & 9440.945 & 12930.270 & 1 & 4797 & 127628 \\
\hline Leverage at IPO & 399 & 3.738 & 3.309 & -11.5 & 2.796 & 36.309 \\
\hline Lead arranger's reputation (\%) & 399 & 21.238 & 11.411 & 0.086 & 21.631 & 50.952 \\
\hline JASDAQ after offer price (\%) & 399 & 1.130 & 9.050 & -21.030 & 0.173 & 60.881 \\
\hline JASDAQ runup (40 days) (\%) & 399 & 0.904 & 10.615 & -27.468 & 0.393 & 39.288 \\
\hline Metropolitan $(0,1)$ & 399 & 0.602 & 0.490 & & & \\
\hline Tangibility pre-IPO & 399 & 0.216 & 0.206 & 0 & 0.156 & 0.921 \\
\hline lead VC capital (million JPY) & 316 & 9134.472 & 13606.360 & 2 & 2950 & 100000 \\
\hline lead VC age at IPO (years) & 299 & 22.013 & 11.619 & 0.132 & 22.129 & 47.334 \\
\hline
\end{tabular}

Note. ${ }^{*}, * *$, and $* * *$ indicate that the difference of the means of those without bank relationships through loans and VC subsidiaries and those with them is statistically significant at a $10 \%, 5 \%$, and $1 \%$ significance level, respectively (one-sided). 
Table 8. Correlation matrix of variables.

\begin{tabular}{|c|c|c|c|c|c|c|c|c|c|}
\hline Variable & $\overline{1}$ & $\overline{2}$ & $\overline{3}$ & 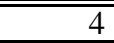 & $\overline{5}$ & $\overline{6}$ & $\overline{7}$ & 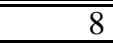 & $\overline{9}$ \\
\hline 1 Initial return & 1.000 & & & & & & & & \\
\hline 2 Lead arranger-VC affiliation & -0.059 & 1.000 & & & & & & & \\
\hline 3 Bank-VC affiliation & -0.114 & 0.351 & 1.000 & & & & & & \\
\hline 4 Regional bank-VC affiliation & -0.085 & 0.178 & 0.444 & 1.000 & & & & & \\
\hline 5 Pre-IPO loan & -0.158 & 0.079 & 0.171 & 0.238 & 1.000 & & & & \\
\hline 6 Pre-IPO loan \& bank-VC affiliation & -0.174 & 0.274 & 0.700 & 0.447 & 0.700 & 1.000 & & & \\
\hline 7 Pre-IPO loan / asset & -0.089 & 0.002 & 0.109 & 0.201 & 0.567 & 0.408 & 1.000 & & \\
\hline 8 Log of firm age at IPO & -0.199 & 0.114 & 0.179 & 0.198 & 0.258 & 0.268 & 0.205 & 1.000 & \\
\hline 9 Log of funding amount & 0.011 & 0.079 & -0.033 & -0.064 & -0.032 & -0.018 & -0.037 & -0.082 & 1.000 \\
\hline 10 EBITDA / sales at IPO & 0.020 & -0.038 & -0.024 & -0.050 & -0.022 & -0.032 & 0.020 & 0.010 & -0.080 \\
\hline $11 \mathrm{Log}$ of sales at IPO & -0.215 & 0.079 & 0.115 & 0.103 & 0.334 & 0.282 & 0.312 & 0.435 & 0.059 \\
\hline 12 Leverage at IPO & -0.113 & -0.024 & 0.048 & 0.052 & 0.270 & 0.179 & 0.551 & 0.138 & -0.027 \\
\hline 13 Lead arranger's reputation & -0.062 & 0.217 & 0.046 & 0.117 & -0.046 & -0.011 & -0.033 & 0.058 & 0.174 \\
\hline 14 High-tech & 0.029 & 0.035 & -0.015 & -0.061 & -0.178 & -0.138 & -0.247 & -0.163 & 0.120 \\
\hline 15 JASDAQ after offer price & 0.234 & -0.025 & 0.050 & 0.009 & 0.024 & 0.056 & -0.015 & 0.035 & -0.015 \\
\hline 16 JASDAQ run-up (40 days) & 0.186 & -0.060 & 0.011 & 0.041 & 0.013 & 0.032 & 0.012 & 0.022 & 0.033 \\
\hline 17 Metropolitan & 0.073 & -0.047 & -0.138 & -0.386 & -0.176 & -0.228 & -0.126 & -0.226 & 0.050 \\
\hline 18 Tangibility pre-IPO & -0.199 & 0.140 & 0.189 & 0.202 & 0.317 & 0.340 & 0.392 & 0.313 & 0.041 \\
\hline Variable & 10 & 11 & 12 & 13 & 14 & 15 & 16 & 17 & \\
\hline 10 EBITDA / sales at IPO & 1.000 & & & & & & & & \\
\hline $11 \mathrm{Log}$ of sales at IPO & 0.262 & 1.000 & & & & & & & \\
\hline 12 Leverage at IPO & 0.027 & 0.319 & 1.000 & & & & & & \\
\hline 13 Lead arranger's reputation & -0.008 & 0.078 & -0.035 & 1.000 & & & & & \\
\hline 14 High-tech & -0.067 & -0.344 & -0.206 & -0.036 & 1.000 & & & & \\
\hline 15 JASDAQ after offer price & -0.003 & 0.081 & -0.001 & -0.019 & -0.070 & 1.000 & & & \\
\hline 16 JASDAQ run-up (40 days) & -0.004 & 0.048 & 0.032 & -0.006 & -0.041 & 0.073 & 1.000 & & \\
\hline 17 Metropolitan & 0.059 & -0.079 & -0.062 & -0.078 & 0.116 & -0.021 & -0.091 & 1.000 & \\
\hline 18 Tangibility pre-IPO & 0.022 & 0.258 & 0.223 & 0.025 & -0.161 & 0.000 & 0.054 & -0.275 & \\
\hline
\end{tabular}


Table 9. Certification Effect: IPO Year Fixed-Effect Regression Excluding Outliers

Notes. Dependent variable is the initial return. The coefficients are estimated by the IPO-year fixed effect regression. The outliers, which reports the initial return in top and bottom $1 \%$, are dropped from the sample. The numbers in parentheses are the IPO-year cluster-robust standard error of each coefficient. The estimated constant term is omitted from the table. *, **, and *** indicate that the estimated coefficient is different from zero at a $10 \%, 5 \%$, and $1 \%$ statistical significance level, respectively (two-sided).

\begin{tabular}{|c|c|c|c|c|c|c|c|}
\hline 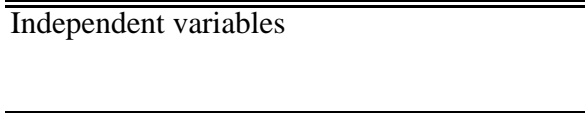 & $\begin{array}{r}(1) \\
\text { Coef. } \\
\text { (s.e.) }\end{array}$ & $\begin{array}{r}(2) \\
\text { Coef. } \\
\text { (s.e.) }\end{array}$ & $\begin{array}{r}(3) \\
\text { Coef. } \\
\text { (s.e.) }\end{array}$ & $\begin{array}{r}(4) \\
\text { Coef. } \\
\text { (s.e.) }\end{array}$ & $\begin{array}{r}(5) \\
\text { Coef. } \\
\text { (s.e.) }\end{array}$ & $\begin{array}{r}(6) \\
\text { Coef. } \\
\text { (s.e.) }\end{array}$ & \\
\hline$\overline{\text { Bank-VC affiliation }}$ & $\begin{array}{c}-13.618^{* *} \\
(4.459)\end{array}$ & & $\begin{array}{c}-12.2411^{* *} \\
(4.431)\end{array}$ & & & & \\
\hline Pre-IPO loan & & $\begin{array}{c}-14.474 * * \\
(6.243)\end{array}$ & $\begin{array}{c}-13.009 * \\
(6.544)\end{array}$ & & & & \\
\hline Pre-IPO loan \& bank-VC affiliation & & & & $\begin{array}{l}-20.771 * * * \\
(3.613)\end{array}$ & & $\begin{array}{r}-17.073 \\
(6.584)\end{array}$ & $* *$ \\
\hline Pre-IPO loan / asset & & & & & $\begin{array}{c}21.742 \\
(24.427)\end{array}$ & & \\
\hline Pre-IPO loan \& regional bank-VC affiliation & & & & & & $\begin{array}{c}-6.565 \\
(10.322)\end{array}$ & \\
\hline Log of firm age at IPO & $\begin{array}{c}-19.375 * * \\
(7.154)\end{array}$ & $\begin{array}{c}-19.557 * * \\
(7.657)\end{array}$ & $\begin{array}{c}-18.606 * * \\
(7.674)\end{array}$ & $\begin{array}{c}-18.335 * * \\
(7.353)\end{array}$ & $\begin{array}{c}-21.014 * * \\
(7.280)\end{array}$ & $\begin{array}{r}-18.080 \\
(7.655)\end{array}$ & $* *$ \\
\hline Log of funding amount & $\begin{array}{l}-3.404 \\
(5.290)\end{array}$ & $\begin{array}{l}-3.285 \\
(4.947)\end{array}$ & $\begin{array}{l}-3.601 \\
(5.113)\end{array}$ & $\begin{array}{l}-3.340 \\
(5.096)\end{array}$ & $\begin{array}{l}-2.908 \\
(5.193)\end{array}$ & $\begin{array}{l}-3.445 \\
(4.993)\end{array}$ & \\
\hline EBITDA / sales at IPO & $\begin{array}{l}0.003 \\
(0.000)\end{array}$ & ${ }^{0.003}{ }^{* * *}$ & $\begin{array}{l}0.003 \\
(0.000)\end{array}$ & ${ }^{0.003}{ }^{* * *}$ & $\begin{array}{l}0.003 * * * \\
(0.000)\end{array}$ & $\begin{array}{c}0.003 \\
(0.000)\end{array}$ & $* * *$ \\
\hline Log of sales at IPO & $\begin{array}{c}-13.910 * * * \\
(3.656)\end{array}$ & $\begin{array}{c}-12.959 * * * \\
(3.841)\end{array}$ & $\begin{array}{l}-12.946 * * * \\
(3.880)\end{array}$ & $\begin{array}{l}-12.724 * * * \\
(3.864)\end{array}$ & $\begin{array}{l}-14.363 * * * \\
(3.539)\end{array}$ & $\begin{array}{r}-12.822 \\
(3.803)\end{array}$ & $* * *$ \\
\hline Leverage at IPO & $\begin{array}{l}-1.185 \\
(0.759)\end{array}$ & $\begin{array}{l}-0.896 \\
(0.858)\end{array}$ & $\begin{array}{l}-0.895 \\
(0.775)\end{array}$ & $\begin{array}{l}-0.930 \\
(0.778)\end{array}$ & $\begin{array}{l}-1.919 \\
(1.108)\end{array}$ & $\begin{array}{l}-0.924 \\
(0.799)\end{array}$ & \\
\hline Lead arranger's reputation & $\begin{array}{c}0.191 \\
(0.524)\end{array}$ & $\begin{array}{c}0.118 \\
(0.497)\end{array}$ & $\begin{array}{c}0.173 \\
(0.503)\end{array}$ & $\begin{array}{c}0.160 \\
(0.506)\end{array}$ & $\begin{array}{c}0.129 \\
(0.532)\end{array}$ & $\begin{array}{r}0.186 \\
(0.514)\end{array}$ & \\
\hline JASDAQ after offer price & $\begin{array}{l}1.782^{* * *} \\
(0.176)\end{array}$ & $\left.{ }^{1.765}\right)^{* * *}$ & $1^{1.787^{* * *}}$ & $l^{1.792^{* * *}}$ & $\begin{array}{l}1.769 * * * \\
(0.196)\end{array}$ & $\begin{array}{c}1.780 \\
(0.148)\end{array}$ & $* * *$ \\
\hline JASDAQ run-up (40 days) & $\begin{array}{l}1.6977^{* * *} \\
(0.430)\end{array}$ & $\begin{array}{l}1.678 \text { *** } \\
(0.432)\end{array}$ & $\begin{array}{l}1.6811^{* * *} \\
(0.426)\end{array}$ & $\begin{array}{l}1.694^{* * *} \\
(0.421)\end{array}$ & $\begin{array}{l}1.702 \text { *** } \\
(0.435)\end{array}$ & $\begin{array}{r}1.703 \\
(0.431)\end{array}$ & $* * *$ \\
\hline High-tech & $\begin{array}{l}-3.002 \\
(6.935) \\
\end{array}$ & $\begin{array}{l}-4.155 \\
(6.648) \\
\end{array}$ & $\begin{array}{l}-3.653 \\
(6.766) \\
\end{array}$ & $\begin{array}{l}-4.137 \\
(6.930) \\
\end{array}$ & $\begin{array}{l}-2.433 \\
(6.089)\end{array}$ & $\begin{array}{l}-4.291 \\
(6.812)\end{array}$ & \\
\hline IPO year fixed effect & yes & yes & yes & yes & yes & yes & \\
\hline $\begin{array}{l}\text { F-test for IPO-year fixed effect } \\
\text { (p-value) }\end{array}$ & $\begin{array}{r}9.53 \\
(0.000)\end{array}$ & $\begin{array}{r}9.61 \\
(0.000)\end{array}$ & $\begin{array}{r}9.61 \\
(0.000)\end{array}$ & $\begin{array}{r}9.62 \\
(0.000)\end{array}$ & $\begin{array}{r}9.46 \\
(0.000)\end{array}$ & $\begin{array}{r}9.64 \\
(0.000)\end{array}$ & \\
\hline R-sq (within) & 0.134 & 0.134 & 0.136 & 0.140 & 0.131 & 0.141 & \\
\hline (between) & 0.192 & 0.165 & 0.156 & 0.153 & 0.226 & 0.153 & \\
\hline (overall) & 0.146 & 0.145 & 0.147 & 0.151 & 0.145 & 0.151 & \\
\hline $\mathrm{N}$ & 656 & 656 & 656 & 656 & 656 & 656 & \\
\hline
\end{tabular}


Table 10. Certification Effect: Longer controls, IPO year fixed-effect regression excluding outliers

Notes. Dependent variable is the initial return. The coefficients are estimated by the IPO-year fixed effect regression. The outliers, which reports the initial return in top and bottom $1 \%$, are dropped from the sample. The numbers in parentheses are the IPO-year cluster-robust standard error of each coefficient. The estimated constant term is omitted from the table. *, **, and $* * *$ indicate that the estimated coefficient is different from zero at a $10 \%, 5 \%$, and $1 \%$ statistical significance level, respectively (two-sided)

\begin{tabular}{|c|c|c|c|c|c|c|}
\hline $\begin{array}{c}\text { Independent variables } \\
\end{array}$ & $\begin{array}{r}(1) \\
\text { Coef. } \\
\text { (s.e.) }\end{array}$ & $\begin{array}{r}(2) \\
\text { Coef. } \\
\text { (s.e.) }\end{array}$ & $\begin{array}{r}\text { (3) } \\
\text { Coef. } \\
\text { (s.e.) }\end{array}$ & $\begin{array}{r}(4) \\
\text { Coef. } \\
\text { (s.e.) }\end{array}$ & $\begin{array}{r}\text { (5) } \\
\text { Coef. } \\
\text { (s.e.) }\end{array}$ & $\begin{array}{r}\text { (6) } \\
\text { Coef. } \\
\text { (s.e.) }\end{array}$ \\
\hline Bank-VC affiliation & $\begin{array}{l}-19.351 \\
(11.053)\end{array}$ & & $\begin{array}{l}-17.320 \\
(10.348)\end{array}$ & & & \\
\hline Pre-IPO loan & & $\begin{array}{l}-17.264 \\
(10.526)\end{array}$ & $\begin{array}{r}-15.155 \\
(9.986)\end{array}$ & & & \\
\hline Pre-IPO loan \& bank-VC affiliation & & & & $\begin{array}{c}-21.725 * * \\
(9.680)\end{array}$ & & $\begin{array}{c}-18.170 * \\
(8.321)\end{array}$ \\
\hline Pre-IPO loan / asset & & & & & $\begin{array}{c}17.744 \\
(39.702)\end{array}$ & \\
\hline Pre-IPO loan \& regional bank-VC affiliation & & & & & & $\begin{array}{c}-6.199 \\
(10.099)\end{array}$ \\
\hline Log of firm age at IPO & $\begin{array}{c}-19.548)^{* *} \\
(8.617)\end{array}$ & $\begin{array}{c}-19.207 * \\
(9.116)\end{array}$ & $\begin{array}{c}-18.313 * \\
(9.454)\end{array}$ & $\begin{array}{c}-18.677 * \\
(9.197)\end{array}$ & $\begin{array}{c}-21.0822^{* *} \\
(8.243)\end{array}$ & $\begin{array}{c}-18.477 * \\
(9.434)\end{array}$ \\
\hline Log of funding amount & $\begin{array}{l}-0.694 \\
(5.401)\end{array}$ & $\begin{array}{l}-0.662 \\
(4.998)\end{array}$ & $\begin{array}{l}-0.889 \\
(5.071)\end{array}$ & $\begin{array}{l}-0.672 \\
(5.083)\end{array}$ & $\begin{array}{l}-0.247 \\
(5.575)\end{array}$ & $\begin{array}{l}-0.700 \\
(5.081)\end{array}$ \\
\hline EBITDA / sales at IPO & $\begin{array}{l}0.003 * * * \\
(0.000)\end{array}$ & $\begin{array}{l}0.003 \\
(0.000)\end{array}$ & $\begin{array}{l}0.003 * * * \\
(0.000)\end{array}$ & $\begin{array}{l}0.003 * * * \\
(0.000)\end{array}$ & $\begin{array}{l}0.004 \\
(0.000)\end{array}$ & $\begin{array}{l}0.003 * * * \\
(0.000)\end{array}$ \\
\hline Log of sales at IPO & $\begin{array}{l}-16.083 * * * \\
(3.263)\end{array}$ & $\begin{array}{l}-15.295 * * * \\
(3.490)\end{array}$ & $\begin{array}{l}-15.2488^{* * *} \\
(3.375)\end{array}$ & $\begin{array}{l}-15.1144^{* * *} \\
(3.357)\end{array}$ & $\begin{array}{l}-16.406^{* * *} \\
(3.282)\end{array}$ & $\begin{array}{c}-15.284 \\
(3.329)\end{array}$ \\
\hline Leverage at IPO & $\begin{array}{l}-1.839 * \\
(0.942)\end{array}$ & $\begin{array}{l}-1.456 \\
(1.140)\end{array}$ & $\begin{array}{l}-1.427 \\
(1.068)\end{array}$ & $\begin{array}{l}-1.477 \\
(1.042)\end{array}$ & $\begin{array}{l}-2.580 \\
(2.129)\end{array}$ & $\begin{array}{l}-1.404 \\
(1.055)\end{array}$ \\
\hline Lead arranger's reputation & $\begin{array}{c}0.152 \\
(0.552)\end{array}$ & $\begin{array}{c}0.079 \\
(0.528)\end{array}$ & $\begin{array}{c}0.142 \\
(0.531)\end{array}$ & $\begin{array}{c}0.129 \\
(0.529)\end{array}$ & $\begin{array}{c}0.080 \\
(0.565)\end{array}$ & $\begin{array}{c}0.154 \\
(0.533)\end{array}$ \\
\hline JASDAQ after offer price & $\begin{array}{l}2.213 * * * \\
(0.556)\end{array}$ & $\begin{array}{l}2.199 \\
(0.533)\end{array}$ & $\begin{array}{l}2.217 \\
(0.541)\end{array}$ & $\begin{array}{l}2.212 \\
(0.533)\end{array}$ & $\begin{array}{l}2.202 \\
(0.571)\end{array}$ & $\begin{array}{l}2.190 \\
(0.523)\end{array}$ \\
\hline JASDAQ run-up (40 days) & $\begin{array}{l}2.515 \\
(0.527)\end{array}$ & 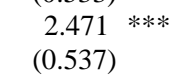 & $\begin{array}{l}2.462 \\
(0.522)\end{array}$ & ${ }^{2.500}{ }^{* * *}$ & ${ }^{2.538}{ }^{* * *}$ & $\begin{array}{l}2.509 * * * \\
(0.540)\end{array}$ \\
\hline High-tech & $\begin{array}{r}-(8.976) \\
(8.160)\end{array}$ & $\begin{array}{r}-(10.119) \\
(8.254)\end{array}$ & $\begin{array}{r}-(9.645) \\
(8.475)\end{array}$ & $\begin{array}{r}-(9.936) \\
(8.064)\end{array}$ & $\begin{array}{r}-(8.574) \\
(7.813)\end{array}$ & $\begin{array}{r}-(10.357) \\
(7.802)\end{array}$ \\
\hline Log of lead VC capital & $\begin{array}{l}-1.062 \\
(1.915)\end{array}$ & $\begin{array}{l}-0.723 \\
(1.912)\end{array}$ & $\begin{array}{l}-0.862 \\
(1.850)\end{array}$ & $\begin{array}{l}-0.902 \\
(1.817)\end{array}$ & $\begin{array}{l}-0.889 \\
(1.978)\end{array}$ & $\begin{array}{l}-0.888 \\
(1.812)\end{array}$ \\
\hline Log of lead VC age & $\begin{array}{c}2.594 \\
(6.134) \\
\end{array}$ & $\begin{array}{c}1.473 \\
(6.085) \\
\end{array}$ & $\begin{array}{r}2.119 \\
(5.807) \\
\end{array}$ & $\begin{array}{r}2.071 \\
(5.932) \\
\end{array}$ & $\begin{array}{r}1.609 \\
(6.718) \\
\end{array}$ & $\begin{array}{r}2.053 \\
(6.034) \\
\end{array}$ \\
\hline IPO year fixed effect & yes & yes & yes & yes & yes & yes \\
\hline $\begin{array}{l}\text { F-test for IPO-year fixed effect } \\
\text { (p-value) }\end{array}$ & $\begin{array}{c}5.76 \\
(0.000)\end{array}$ & $\begin{array}{c}6.02 \\
(0.000)\end{array}$ & $\begin{array}{c}5.85 \\
(0.000)\end{array}$ & $\begin{array}{c}5.79 \\
(0.000)\end{array}$ & $\begin{array}{c}5.88 \\
(0.000)\end{array}$ & $\begin{array}{c}5.80 \\
(0.000)\end{array}$ \\
\hline R-sq (within) & 0.169 & 0.168 & 0.172 & 0.173 & 0.164 & 0.174 \\
\hline (between) & 0.106 & 0.070 & 0.079 & 0.085 & 0.107 & 0.084 \\
\hline (overall) & 0.182 & 0.177 & 0.183 & 0.186 & 0.176 & 0.186 \\
\hline $\mathrm{N}$ & 452 & 452 & 452 & 452 & 452 & 452 \\
\hline
\end{tabular}


Table 11. Information revelation: IPO year fixed effect regression excluding outliers

Notes. Dependent variable is the initial return. The coefficients are estimated by the IPO-year fixed effect regression. The outliers, which reports the initial return in top and bottom $1 \%$, are dropped from the sample. The numbers in parentheses are the IPO-year clusterrobust standard error of each coefficient. The estimated constant term is omitted from the table. *, **, and *** indicate that the estimated coefficient is different from zero at a $10 \%, 5 \%$, and $1 \%$ statistical significance level, respectively (two-sided).

\begin{tabular}{|c|c|c|c|c|}
\hline 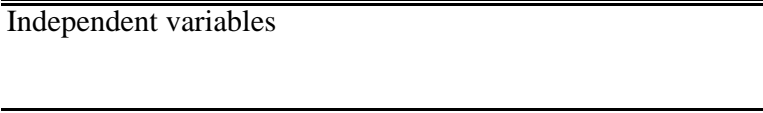 & $\begin{array}{r}(1) \\
\text { Coef. } \\
\text { (s.e.) }\end{array}$ & $\begin{array}{r}(2) \\
\text { Coef. } \\
\text { (s.e.) }\end{array}$ & $\begin{array}{r}(3) \\
\text { Coef. } \\
\text { (s.e.) }\end{array}$ & $\begin{array}{r}(4) \\
\text { Coef. } \\
\text { (s.e.) }\end{array}$ \\
\hline Lead arranger-VC affiliation & $\begin{array}{c}2.913 \\
(11.204)\end{array}$ & $\begin{array}{c}8.808 \\
(11.599)\end{array}$ & & \\
\hline Pre-IPO loan \& bank-VC affiliation & & $\begin{array}{l}-23.212 * * * \\
(4.433)\end{array}$ & & $\begin{array}{l}-17.776 * * * \\
(4.784)\end{array}$ \\
\hline $\begin{array}{l}\text { Pre-IPO loan \& large bank/security company-VC affiliation } \\
\text { (Could) }\end{array}$ & & & $\begin{array}{c}-15.643 * \\
(7.469)\end{array}$ & $\begin{array}{r}-11.369 \\
(7.751)\end{array}$ \\
\hline $\begin{array}{l}\text { Pre-IPO loan \& large bank/security company-VC affiliation } \\
\text { \& lead arranger-VC affiliated (Did) }\end{array}$ & & & $\begin{array}{c}-2.118 \\
(12.668)\end{array}$ & $\begin{array}{c}3.860 \\
(14.092)\end{array}$ \\
\hline Log of firm age at IPO & $\begin{array}{l}-20.690 * * \\
(7.485)\end{array}$ & $\begin{array}{l}-18.516 * * \\
(7.642)\end{array}$ & $\begin{array}{l}-20.559 * * \\
(6.846)\end{array}$ & $\begin{array}{l}-18.784 \\
(7.176)\end{array}$ \\
\hline Log of funding amount & $\begin{array}{l}-3.056 \\
(5.117)\end{array}$ & $\begin{array}{l}-3.476 \\
(5.092)\end{array}$ & $\begin{array}{l}-2.785 \\
(5.028)\end{array}$ & $\begin{array}{l}-3.181 \\
(5.017)\end{array}$ \\
\hline EBITDA / sales at IPO & $\begin{array}{l}0.003 * * * \\
(0.000)\end{array}$ & $\begin{array}{l}0.003 * * * \\
(0.000)\end{array}$ & $\begin{array}{l}0.003 * * * \\
(0.000)\end{array}$ & $\begin{array}{l}0.003^{* * *} \\
(0.000)\end{array}$ \\
\hline Log of sales at IPO & $\begin{array}{l}-14.125 * * * \\
(3.540)\end{array}$ & $\begin{array}{l}-12.806 * * * \\
(3.906)\end{array}$ & $\begin{array}{l}-14.139 * * * \\
(3.633)\end{array}$ & $\begin{array}{l}-13.150^{* * *} \\
(3.952)\end{array}$ \\
\hline Leverage at IPO & $\begin{array}{l}-1.204 \\
(0.836)\end{array}$ & $\begin{array}{l}-0.838 \\
(0.782)\end{array}$ & $\begin{array}{l}-1.259 \\
(0.733)\end{array}$ & $\begin{array}{l}-0.988 \\
(0.690)\end{array}$ \\
\hline Lead arranger's reputation & $\begin{array}{c}0.104 \\
(0.600)\end{array}$ & $\begin{array}{c}0.082 \\
(0.591)\end{array}$ & $\begin{array}{c}0.169 \\
(0.523)\end{array}$ & $\begin{array}{c}0.192 \\
(0.515)\end{array}$ \\
\hline JASDAQ after offer price & $\begin{array}{l}1.758 * * * \\
(0.185)\end{array}$ & $\begin{array}{l}1.801)^{* * *} \\
(0.168)\end{array}$ & $\begin{array}{l}1.744 * * * \\
(0.141)\end{array}$ & $\begin{array}{l}1.766^{* * *} \\
(0.131)\end{array}$ \\
\hline JASDAQ run-up (40 days) & $\begin{array}{l}1.704 * * * \\
(0.423)\end{array}$ & $\begin{array}{l}1.721)^{* * *} \\
(0.411)\end{array}$ & $\begin{array}{l}1.670 * * * \\
(0.390)\end{array}$ & $\begin{array}{l}1.686 * * * \\
(0.395)\end{array}$ \\
\hline High-tech & $\begin{array}{l}-3.693 \\
(7.439) \\
\end{array}$ & $\begin{array}{l}-4.840 \\
(7.556) \\
\end{array}$ & $\begin{array}{l}-2.037 \\
(7.154) \\
\end{array}$ & $\begin{array}{l}-3.112 \\
(7.342) \\
\end{array}$ \\
\hline IPO year fixed effect & yes & yes & yes & yes \\
\hline $\begin{array}{l}\text { F-test for IPO-year fixed effect } \\
\text { (p-value) }\end{array}$ & $\begin{array}{c}9.470 \\
(0.000)\end{array}$ & $\begin{array}{c}9.540 \\
(0.000)\end{array}$ & $\begin{array}{c}9.280 \\
(0.000)\end{array}$ & $\begin{array}{c}9.400 \\
(0.000)\end{array}$ \\
\hline R-sq (within) & 0.130 & 0.142 & 0.137 & 0.143 \\
\hline (between) & 0.210 & 0.155 & 0.231 & 0.180 \\
\hline (overall) & 0.144 & 0.153 & 0.153 & 0.156 \\
\hline $\mathrm{N}$ & 656 & 656 & 656 & 656 \\
\hline
\end{tabular}


Table 12. Information revelation: Long controls, IPO year fixed effect regression excluding outliers

Notes. Dependent variable is the initial return. The coefficients are estimated by the IPO-year fixed effect regression. The outliers, which reports the initial return in top and bottom $1 \%$, are dropped from the sample. The numbers in parentheses are the IPO-year cluster-robust standard error of each coefficient. The estimated constant term is omitted from the table. *, **, and *** indicate that the estimated coefficient is different from zero at a $10 \%, 5 \%$, and $1 \%$ statistical significance level, respectively (two-sided).

\begin{tabular}{|c|c|c|c|c|c|}
\hline 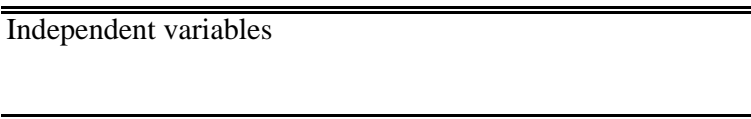 & $\begin{array}{r}(1) \\
\text { Coef. } \\
\text { (s.e.) }\end{array}$ & $\begin{array}{r}(2) \\
\text { Coef. } \\
\text { (s.e.) }\end{array}$ & $\begin{array}{r}(3) \\
\text { Coef. } \\
\text { (s.e.) }\end{array}$ & $\begin{array}{r}(4) \\
\text { Coef. } \\
\text { (s.e.) } \\
\end{array}$ & \\
\hline Lead arranger-VC affiliation & $\begin{array}{c}-0.370 \\
(13.929)\end{array}$ & $\begin{array}{c}4.574 \\
(13.556)\end{array}$ & & & \\
\hline Pre-IPO loan \& bank-VC affiliation & & $\begin{array}{l}-22.807 * * \\
(9.361)\end{array}$ & & $\begin{array}{l}-18.621 \\
(11.366)\end{array}$ & \\
\hline $\begin{array}{l}\text { Pre-IPO loan \& large bank/security company-VC affiliation } \\
\text { (Could) }\end{array}$ & & & $\begin{array}{c}-19.933 * \\
(9.622)\end{array}$ & $\begin{array}{r}-17.113 \\
(9.774)\end{array}$ & \\
\hline $\begin{array}{l}\text { Pre-IPO loan \& large bank/security company-VC affiliation } \\
\text { \& lead arranger-VC affiliated (Did) }\end{array}$ & & & $\begin{array}{c}-2.084 \\
(10.458)\end{array}$ & $\begin{array}{c}4.577 \\
(12.254)\end{array}$ & \\
\hline Log of firm age at IPO & $\begin{array}{l}-20.764 * * \\
(7.829)\end{array}$ & $\begin{array}{c}-18.507 * \\
(8.884)\end{array}$ & $\begin{array}{l}-21.451 * * \\
(8.231)\end{array}$ & $\begin{array}{r}-19.665 \\
(9.209)\end{array}$ & * \\
\hline Log of funding amount & $\begin{array}{l}-0.389 \\
(5.196)\end{array}$ & $\begin{array}{l}-0.884 \\
(4.858)\end{array}$ & $\begin{array}{l}-0.105 \\
(5.033)\end{array}$ & $\begin{array}{l}-0.489 \\
(4.803)\end{array}$ & \\
\hline EBITDA / sales at IPO & ${ }^{0.003}{ }^{* * *}$ & $\begin{array}{l}0.003 * * * \\
(0.000)\end{array}$ & $\begin{array}{l}0.003 * * * \\
(0.000)\end{array}$ & $\begin{array}{r}0.003 \\
(0.000)\end{array}$ & $* * *$ \\
\hline Log of sales at IPO & $\begin{array}{l}-16.253 * * * \\
(3.105)\end{array}$ & $\begin{array}{l}-15.235 * * * \\
(3.189)\end{array}$ & $\begin{array}{l}-16.226 * * * \\
(3.465)\end{array}$ & $\begin{array}{r}-15.436 \\
(3.504)\end{array}$ & $* * *$ \\
\hline Leverage at IPO & $\begin{array}{l}-1.936 * \\
(0.993)\end{array}$ & $\begin{array}{l}-1.459 \\
(1.040)\end{array}$ & $\begin{array}{l}-1.895 * \\
(1.014)\end{array}$ & $\begin{array}{l}-1.478 \\
(1.087)\end{array}$ & \\
\hline Lead arranger's reputation & $\begin{array}{c}0.086 \\
(0.654)\end{array}$ & $\begin{array}{c}0.092 \\
(0.628)\end{array}$ & $\begin{array}{r}0.090 \\
(0.559)\end{array}$ & $\begin{array}{c}0.141 \\
(0.528)\end{array}$ & \\
\hline JASDAQ after offer price & $2.190 * * *$ & $2.227 * * *$ & $2.155 * * *$ & $\begin{array}{r}2.160 \\
(0.513)\end{array}$ & $* * *$ \\
\hline JASDAQ run-up (40 days) & $\begin{array}{l}2.532^{* * *} \\
(0.518)\end{array}$ & $\begin{array}{l}2.5188^{* * *} \\
(0.510)\end{array}$ & $\begin{array}{l}2.475 * * * \\
(0.519)\end{array}$ & $\begin{array}{r}2.471 \\
(0.515)\end{array}$ & $* * *$ \\
\hline High-tech & $\begin{array}{r}-(9.386) \\
(8.413)\end{array}$ & $\begin{array}{r}-(10.231) \\
(8.443)\end{array}$ & $\begin{array}{r}-(6.910) \\
(8.504)\end{array}$ & $\begin{array}{r}-(7.980) \\
(8.656)\end{array}$ & \\
\hline Log of lead VC capital & $\begin{array}{l}-0.931 \\
(1.951)\end{array}$ & $\begin{array}{l}-0.962 \\
(1.773)\end{array}$ & $\begin{array}{c}0.315 \\
(2.137)\end{array}$ & $\begin{array}{r}0.137 \\
(1.995)\end{array}$ & \\
\hline Log of lead VC age & $\begin{array}{c}1.951 \\
(6.841) \\
\end{array}$ & $\begin{array}{r}1.887 \\
(6.349) \\
\end{array}$ & $\begin{array}{r}1.128 \\
(5.889) \\
\end{array}$ & $\begin{array}{r}1.298 \\
(5.658) \\
\end{array}$ & \\
\hline IPO year fixed effect & yes & yes & yes & yes & \\
\hline $\begin{array}{l}\text { F-test for IPO-year fixed effect } \\
\text { (p-value) }\end{array}$ & $\begin{array}{c}5.920 \\
(0.000)\end{array}$ & $\begin{array}{c}5.770 \\
(0.000)\end{array}$ & $\begin{array}{c}5.660 \\
(0.000)\end{array}$ & $\begin{array}{r}5.580 \\
(0.000)\end{array}$ & \\
\hline R-sq (within) & 0.163 & 0.173 & 0.172 & 0.178 & \\
\hline (between) & 0.099 & 0.083 & 0.125 & 0.108 & \\
\hline (overall) & 0.175 & 0.187 & 0.189 & 0.195 & \\
\hline $\mathrm{N}$ & 452 & 452 & 452 & 452 & \\
\hline
\end{tabular}


Table 13. Endogenous Bank Relationship

Notes. Dependent variable of the initial return equation is the initial return, and that of the bank-relation equation is the measure of pre-IPO bank relationship (bank-VC affiliation, pre-IPO loan, and pre-IPO loan \& bank-VC affiliation). The models are estimated by the IPO-year fixed-effect 2SLS, in which the bank relation dummy variables are instrumented. Estimated constant terms are omitted from the report. IPO-year cluster robust standard errors are reported in the parentheses below each estimated coefficient. $*$, **, and $* * *$ indicate that the estimated coefficient is different from zero at a $10 \%, 5 \%$, and $1 \%$ statistical significance level, respectively. The Wald test of the excluded instruments reports F statistic of a degree of freedom $(2,644)$. R-squared is a centerd R-squared in the 2SLS columns.

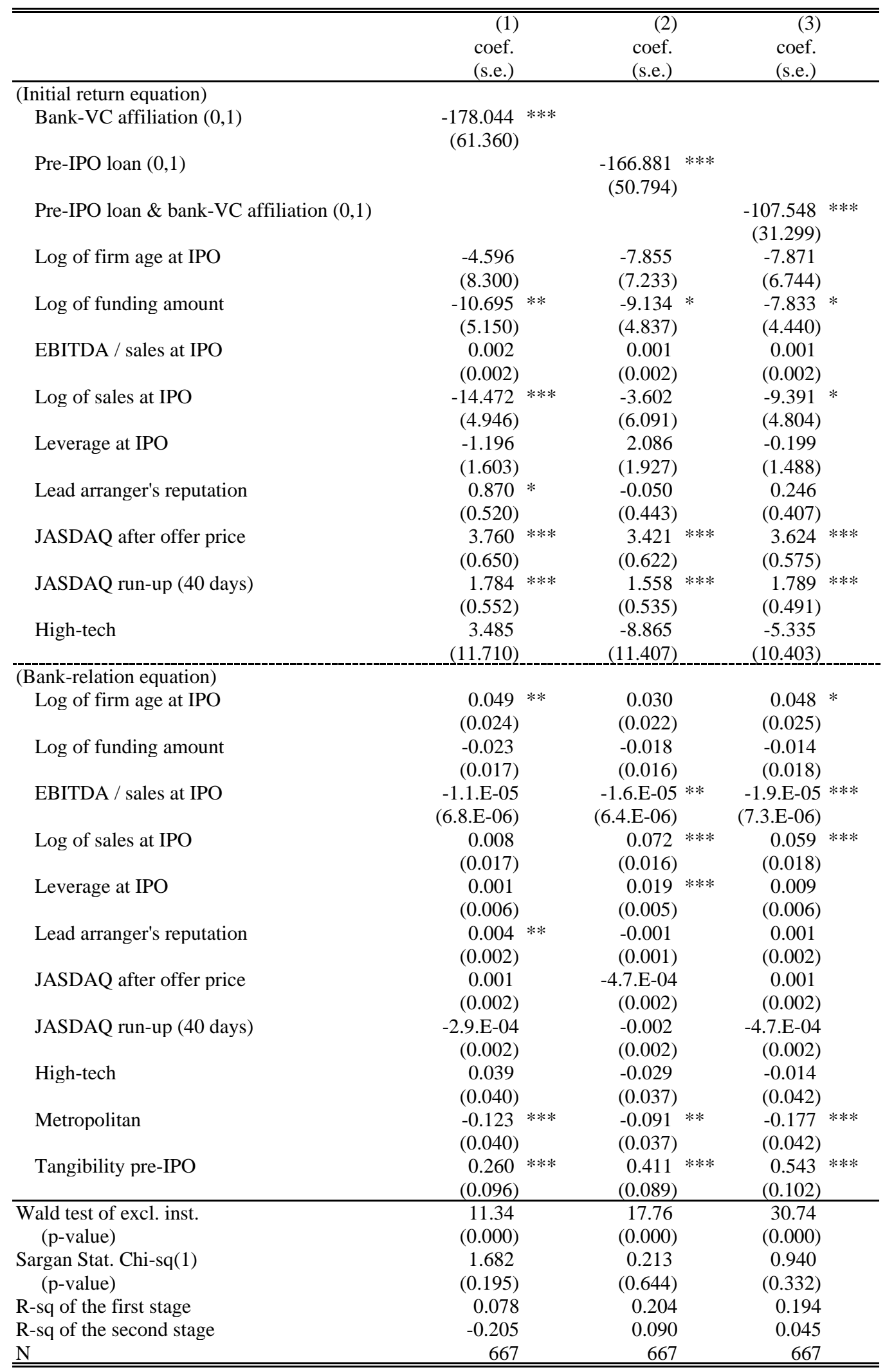


Table 14. Additional definition of variables in the regression analysis

\begin{tabular}{|c|c|}
\hline $\begin{array}{l}\text { Variable } \\
\end{array}$ & Definition \\
\hline$\overline{\text { EBITDA/Sales_t }}$ & $\begin{array}{l}\text { The ratio of EBITDA over Sales, \%. EBITDA is calculated by (operating profit) / (\# } \\
\text { operating days) } * 365+\text { (depreciation). Sales is adjusted by the number of operating } \\
\text { days (sales in the income statement) / (\# operating days) } * 365 . t=0 \text { indicates the last } \\
\text { accounting period before IPO; } t=1 \text { is the next period and so forth. }\end{array}$ \\
\hline ROA_t & $\begin{array}{l}\text { Return on asset, \%. (Ordinary profit) / (\#operating days) } * 365 \text { / (total asset). } t=0 \\
\text { indicates the last accounting period before IPO; } \mathrm{t}=1 \text { is the next period and so forth. }\end{array}$ \\
\hline loan_asset_t & $\begin{array}{l}\text { (long-term borrowing }+ \text { short-term borrowing }+ \text { bonds }+ \text { convertible bonds }+ \\
\text { commercial papers) } / \text { (total asset), \%, at the end of the } t \text { th accounting period after IPO. } \\
t=0 \text { indicates the last accounting period before IPO; } t=1 \text { is the next period and so } \\
\text { forth. }\end{array}$ \\
\hline Sales_growth & $\begin{array}{l}\text { Growth rate of the sales (days adjusted) from the last accounting period before IPO to } \\
\text { three accounting periods later, \%. }\end{array}$ \\
\hline CAR_t & $\begin{array}{l}\text { Cumulative abnormal return in the } \mathrm{t} \text { th year after IPO. } \mathrm{t}=1 \text { indicates the period of the } \\
250 \text { trading days starting from the date of the first trading day. } \mathrm{t}=2 \text { is the next } 250 \\
\text { trading days and so forth. The abnormal return is calculated from the daily rate of } \\
\text { return including dividend (based on the Employee's Pension Insurance evaluation } \\
\text { price) by the OLS of the Fama-French three factor model without the constant term. } \\
\text { HML and SMB factors are those provided by the data vendor, Financial Data Solutions } \\
\text { Inc., which is caclulated from the daily returns including dividend (based on the } \\
\text { Employee's Pension Insurance evaluation price) of all stocks listed in the first section } \\
\text { of the Tokyo Stock Exchange except those in the financial sector. Risk free rate is } \\
\text { measured by the daily yield to maturity of the } 10 \text { year Japanese government bond in } \\
\text { the primary market. }\end{array}$ \\
\hline $\mathrm{SD}(\mathrm{AR}) \_\mathrm{t}$ & Standard deviation of AR_t in the $t$ th accounting period. \\
\hline PD & $\begin{array}{l}\text { Probability of default in the second accounting period after IPO estimated by the KMV } \\
\text { default probability model. Leverage (the ratio of debt over the estimated market value } \\
\text { of total asset) is controlled at } 20 \% \text {. }\end{array}$ \\
\hline $\ln P D$ & Logit transformation of PD, i.e., $\ln ($ PD / (1- PD )). \\
\hline
\end{tabular}


Table 15. Descriptive statistics of variables

\begin{tabular}{|c|c|c|c|c|c|c|}
\hline variable & $\mathrm{N}$ & Mean & s.d. & Min & Med & Max \\
\hline \multicolumn{7}{|l|}{ (a) Full sample } \\
\hline EBITDA/sales_0 (\%) & 624 & 1.45 & 152.29 & -3377.78 & 11.48 & 63.24 \\
\hline EBITDA/sales_1 (\%) & 621 & 4.27 & 92.58 & -1796.97 & 10.83 & 66.83 \\
\hline EBITDA/sales_2 (\%) & 619 & -19.73 & 404.60 & -9310.43 & 8.66 & 72.12 \\
\hline EBITDA/sales_3 (\%) & 603 & -8.46 & 124.88 & -1730.00 & 7.11 & 59.65 \\
\hline ROA_0 (\%) & 624 & 12.35 & 13.87 & -89.27 & 10.84 & 68.11 \\
\hline ROA_1 (\%) & 622 & 8.83 & 12.73 & -134.34 & 8.83 & 53.32 \\
\hline ROA_2 (\%) & 619 & 5.07 & 16.52 & -182.77 & 7.00 & 60.91 \\
\hline ROA_3 (\%) & 602 & 2.38 & 19.87 & -224.52 & 5.56 & 59.00 \\
\hline loan/asset_0 (\%) & 624 & 20.80 & 21.04 & 0.00 & 14.76 & 91.05 \\
\hline loan/asset_1 (\%) & 622 & 17.39 & 19.65 & 0.00 & 10.41 & 88.46 \\
\hline loan/asset_2 (\%) & 619 & 19.40 & 20.93 & 0.00 & 13.20 & 129.45 \\
\hline loan/asset_3 (\%) & 602 & 21.44 & 22.52 & 0.00 & 16.36 & 137.35 \\
\hline PD & 593 & 0.27 & 0.13 & 0.00 & 0.32 & 0.40 \\
\hline CAR_1 (\%) & 630 & 49.96 & 89.99 & -192.75 & 39.95 & 573.51 \\
\hline CAR_2 (\%) & 624 & 48.41 & 98.68 & -260.97 & 36.36 & 382.64 \\
\hline CAR_3 (\%) & 582 & 47.94 & 105.46 & -278.73 & 35.89 & 438.71 \\
\hline SD(AR)_1 (\%) & 630 & 6.44 & 3.14 & 1.48 & 5.74 & 26.67 \\
\hline SD(AR)_2 (\%) & 624 & 5.36 & 2.14 & 1.30 & 5.08 & 19.18 \\
\hline SD(AR)_3 (\%) & 582 & 4.87 & 1.76 & 1.15 & 4.74 & 15.76 \\
\hline Sales_growth (\%) & 604 & 106.13 & 222.66 & -100.00 & 43.74 & 2091.14 \\
\hline \multicolumn{7}{|c|}{ (b) Firms without a bank relationship (pre-IPO loan \& bank-VC affiliation $=0$ ) } \\
\hline EBITDA/sales_0 (\%) & 246 & -8.88 & 234.20 & -3377.78 & $13.87 * * *$ & 63.24 \\
\hline EBITDA/sales_1 (\%) & 244 & 1.01 & 131.23 & -1796.97 & $14.17 * * *$ & 66.83 \\
\hline EBITDA/sales_2 (\%) & 243 & -55.65 & 641.26 & -9310.43 & $9.72 * *$ & 61.77 \\
\hline EBITDA/sales_3 (\%) & 234 & -22.47 & 187.61 & -1730.00 & 7.53 & 59.65 \\
\hline ROA_0 (\%) & 246 & $15.04 * * *$ & 18.34 & -89.27 & $14.68 * * *$ & 68.11 \\
\hline ROA_1 (\%) & 245 & $10.43 * * *$ & 15.56 & -134.34 & $10.89 * * *$ & 53.32 \\
\hline ROA_2 (\%) & 244 & 4.81 & 21.38 & -182.77 & $8.22 * *$ & 60.91 \\
\hline ROA_3 (\%) & 233 & 1.95 & 24.65 & -224.52 & 5.92 & 59.00 \\
\hline loan/asset_0 (\%) & 246 & $10.51 * * *$ & 17.57 & 0.00 & $0.00 * * *$ & 91.05 \\
\hline loan/asset_1 (\%) & 245 & $9.30 * * *$ & 16.59 & 0.00 & $0.00 * * *$ & 78.06 \\
\hline loan/asset_2 (\%) & 244 & $12.07 * * *$ & 19.10 & 0.00 & $0.00 * * *$ & 129.45 \\
\hline loan/asset_3 (\%) & 233 & $13.84 * * *$ & 19.36 & 0.00 & $1.36 * * *$ & 81.57 \\
\hline PD & 234 & $0.24 * * *$ & 0.14 & 0.00 & $0.29 * *$ & 0.40 \\
\hline CAR_1 (\%) & 247 & $55.46 *$ & 88.06 & -192.75 & 45.33 & 322.43 \\
\hline CAR_2 (\%) & 245 & $54.73 * *$ & 101.50 & -244.00 & $48.38 *$ & 329.63 \\
\hline CAR_3 (\%) & 226 & $57.04 *$ & 117.13 & -278.73 & 46.43 & 412.21 \\
\hline SD(AR)_1 (\%) & 247 & $7.02 * * *$ & 2.89 & 1.95 & $6.89 * * *$ & 17.38 \\
\hline SD(AR)_2 (\%) & 245 & $5.80 * * *$ & 1.94 & 1.86 & $5.76 * * *$ & 12.55 \\
\hline SD(AR)_3 (\%) & 226 & $5.23 * * *$ & 1.60 & 1.74 & $5.22 * * *$ & 10.57 \\
\hline Sales_growth (\%) & 235 & 119.55 & 245.21 & -100.00 & $62.17 * *$ & 2091.14 \\
\hline \multicolumn{7}{|c|}{ (c) Firms with bank relationship (pre-IPO loan \& bank-VC affiliation =1) } \\
\hline EBITDA/sales_0 (\%) & 378 & 8.18 & 50.65 & -826.21 & 10.11 & 54.10 \\
\hline EBITDA/sales_1 (\%) & 377 & 6.38 & 54.70 & -862.24 & 9.08 & 66.08 \\
\hline EBITDA/sales_2 (\%) & 376 & 3.49 & 55.13 & -877.19 & 7.52 & 72.12 \\
\hline EBITDA/sales_3 (\%) & 369 & 0.42 & 54.97 & -668.90 & 6.54 & 49.25 \\
\hline ROA_0 (\%) & 378 & 10.60 & 9.57 & -47.46 & 9.23 & 42.36 \\
\hline ROA_1 (\%) & 377 & 7.79 & 10.39 & -79.26 & 7.92 & 32.59 \\
\hline ROA_2 (\%) & 375 & 5.23 & 12.41 & -87.01 & 6.58 & 40.15 \\
\hline ROA_3 (\%) & 369 & 2.65 & 16.17 & -130.33 & 5.32 & 38.20 \\
\hline loan/asset_0 (\%) & 378 & 27.50 & 20.42 & 0.05 & 24.02 & 86.05 \\
\hline loan/asset_1 (\%) & 377 & 22.64 & 19.72 & 0.00 & 18.77 & 88.46 \\
\hline loan/asset_2 (\%) & 375 & 24.18 & 20.70 & 0.00 & 21.27 & 90.45 \\
\hline loan/asset_3 (\%) & 369 & 26.23 & 23.07 & 0.00 & 23.49 & 137.35 \\
\hline PD & 359 & 0.29 & 0.12 & 0.00 & 0.33 & 0.40 \\
\hline CAR_1 (\%) & 383 & 46.41 & 91.16 & -171.74 & 34.04 & 573.51 \\
\hline CAR_2 (\%) & 379 & 44.32 & 96.73 & -260.97 & 31.20 & 382.64 \\
\hline CAR_3 (\%) & 356 & 42.16 & 97.07 & -165.22 & 34.48 & 438.71 \\
\hline SD(AR)_1 (\%) & 383 & 6.06 & 3.24 & 1.48 & 5.31 & 26.67 \\
\hline SD(AR)_2 (\%) & 379 & 5.08 & 2.22 & 1.30 & 4.71 & 19.18 \\
\hline SD(AR)_3 (\%) & 356 & 4.64 & 1.81 & 1.15 & 4.43 & 15.76 \\
\hline Sales_growth (\%) & 369 & 97.58 & 206.92 & -73.92 & 39.43 & 1827.53 \\
\hline
\end{tabular}

Note. $*^{* *}$, and $* * *$ in the column next to mean indicate that the difference of the means of those without bank relationships through loans and VC subsidiaries and those with them is statistically significant at a $10 \%$, $5 \%$, and $1 \%$ significance level, respectively (one-sided). $t$-test is conducted after winthering top and bottom $1 \%$ for each variable. The similar stars in the column next to median indicates the statistical significance of the difference in medians by the median test. 
Table 16. Post-IPO Performance: Industry Fixed-Effect and IPO Year Fixed-Effect Regression Excluding Outliers

Notes. Dependent variable is the initial return. The coefficients are estimated by the industry fixed-effect regression with IPO-year dummy variables. The outliers, which report the initial return in the top and bottom $1 \%$, are dropped from the sample. The numbers in parentheses are the robust standard error of each coefficient. The estimated constant term and the estimated coefficients of IPO-year dummy variables are omitted from the table. Industry classification follows Table 4 . *, **, and $* * *$ indicate that the estimated coefficient is different from zero at a $10 \%, 5 \%$, and $1 \%$ statistical significance level, respectively (two-sided).

(a) Financial performance and leverage

\begin{tabular}{|c|c|c|c|c|c|c|}
\hline & (1) & (2) & (3) & (4) & (5) & (6) \\
\hline dependent variable & EBITDA/sales_1 & EBITDA/sales_3 & ROA_1 & ROA_3 & loan/asset_1 & loan/asset_3 \\
\hline Independent variables & $\begin{array}{r}\text { Coef. } \\
\text { (s.e.) }\end{array}$ & $\begin{array}{l}\text { Coef. } \\
\text { (s.e.) }\end{array}$ & $\begin{array}{l}\text { Coef. } \\
\text { (s.e.) }\end{array}$ & $\begin{array}{r}\text { Coef. } \\
\text { (s.e.) }\end{array}$ & $\begin{array}{r}\text { Coef. } \\
\text { (s.e.) }\end{array}$ & $\begin{array}{l}\text { Coef. } \\
\text { (s.e.) }\end{array}$ \\
\hline \multirow[t]{2}{*}{ Pre-IPO loan \& bank-VC affiliation } & $-2.606 * * *$ & -4.731 & $-1.931 * * *$ & -1.397 & $8.420 * * *$ & $9.409 * * *$ \\
\hline & $(0.655)$ & $(4.867)$ & $(0.368)$ & $(1.248)$ & $(1.150)$ & $(2.113)$ \\
\hline \multirow{2}{*}{ Leverage at IPO } & 0.246 & $1.194 *$ & -0.187 & -0.055 & $1.974 * * *$ & $1.623 * * *$ \\
\hline & $(0.418)$ & $(0.623)$ & $(0.166)$ & $(0.138)$ & $(0.375)$ & $(0.346)$ \\
\hline \multirow[t]{2}{*}{ Log of firm age at IPO } & -0.639 & $3.571 *$ & -0.544 & $1.178 * * *$ & -0.296 & -1.498 \\
\hline & (1.320) & (1.777) & $(0.457)$ & $(0.279)$ & (1.301) & (1.754) \\
\hline \multirow[t]{2}{*}{ Log of total asset at IPO } & -4.191 & $-20.159 *$ & $-5.228 * *$ & $-4.435 * * *$ & $3.378 * *$ & 1.660 \\
\hline & (7.849) & $(9.037)$ & $(1.482)$ & $(0.974)$ & $(1.203)$ & $(2.232)$ \\
\hline \multirow[t]{2}{*}{ Log of sales at IPO } & 6.476 & $29.124 * *$ & $5.626 * * *$ & $6.420 * * *$ & -0.275 & 0.245 \\
\hline & $(8.802)$ & $(11.501)$ & $(1.352)$ & $(1.172)$ & $(1.166)$ & $(1.322)$ \\
\hline \multirow{2}{*}{ Log of \# employees at IPO } & -2.965 & $-6.699 *$ & -0.435 & -0.298 & -0.818 & -0.831 \\
\hline & $(1.745)$ & $(2.851)$ & $(0.424)$ & $(0.615)$ & $(0.716)$ & $(0.518)$ \\
\hline \multirow{2}{*}{$\begin{array}{l}\text { F-test for industry fixed effect } \\
\text { (p-value) }\end{array}$} & 2.530 & 2.660 & 2.990 & 1.710 & 10.930 & 7.740 \\
\hline & $(0.014)$ & $(0.010)$ & $(0.004)$ & $(0.103)$ & $(0.00)$ & $(0.00)$ \\
\hline \multirow{2}{*}{$\begin{array}{l}\text { F-test for IPO-year fixed effect } \\
\text { (p-value) }\end{array}$} & 4.980 & 2.070 & 0.290 & 1.140 & 1.320 & 1.570 \\
\hline & $(0.000)$ & $(0.031)$ & $(0.978)$ & $(0.331)$ & $(0.225)$ & $(0.121)$ \\
\hline R-sq (within) & 0.099 & 0.161 & 0.152 & 0.098 & 0.280 & 0.147 \\
\hline (between) & 0.510 & 0.001 & 0.001 & 0.116 & 0.798 & 0.641 \\
\hline (overall) & 0.080 & 0.141 & 0.127 & 0.105 & 0.359 & 0.209 \\
\hline$\underline{\mathrm{N}}$ & 608 & 591 & 609 & 590 & 621 & 602 \\
\hline \multicolumn{7}{|l|}{ (b) Market performance and growth } \\
\hline \multirow{4}{*}{ dependent variable } & 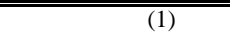 & $\overline{(2)}$ & (3) & (4) & (5) & 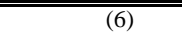 \\
\hline & $\ln P D$ & CAR_1 & CAR_3 & $\mathrm{SD}(\mathrm{AR}) \_1$ & SD(AR)_3 & Sales growth \\
\hline & Coef. & Coef. & Coef. & Coef. & Coef. & Coef. \\
\hline & (s.e.) & (s.e.) & (s.e.) & (s.e.) & (s.e.) & (s.e.) \\
\hline \multirow[t]{2}{*}{ Pre-IPO loan \& bank-VC affiliation } & $0.727 *$ & -4.449 & -9.310 & -0.238 & -0.007 & 22.980 \\
\hline & $(0.340)$ & $(4.502)$ & $(12.373)$ & $(0.230)$ & $(0.122)$ & $(12.877)$ \\
\hline \multirow[t]{2}{*}{ EBITDA/sales_0 } & 0.001 & -1.120 & $-1.394 * *$ & 0.023 & $0.025 * *$ & -1.200 \\
\hline & $(0.001)$ & $(1.096)$ & $(0.560)$ & $(0.022)$ & $(0.011)$ & $(1.163)$ \\
\hline \multirow[t]{2}{*}{ Leverage at IPO } & 0.006 & $-14.492 * * *$ & $-9.561 * * *$ & $-0.332 * *$ & $-0.292 * * *$ & $-45.601 * * *$ \\
\hline & $(0.046)$ & (3.131) & (2.947) & $(0.167)$ & $(0.106)$ & $(7.205)$ \\
\hline \multirow[t]{2}{*}{ Log of firm age at IPO } & -0.023 & $-15.753 * * *$ & -7.073 & $-0.732 * * *$ & $-0.354 * * *$ & -6.558 \\
\hline & $(0.257)$ & (3.145) & $(7.431)$ & $(0.195)$ & $(0.122)$ & (13.648) \\
\hline \multirow[t]{2}{*}{ Log of total asset at IPO } & -0.037 & $13.868 *$ & 5.119 & 0.088 & -0.038 & $-18.944 * *$ \\
\hline & $(0.173)$ & (7.523) & (12.176) & $(0.215)$ & $(0.112)$ & (13.734) \\
\hline \multirow[t]{2}{*}{ Log of sales at IPO } & 0.021 & -3.942 & 1.302 & $-0.205 *$ & $-0.139 * *$ & -0.166 \\
\hline & $(0.121)$ & (6.049) & (6.583) & $(0.110)$ & $(0.064)$ & (8.036) \\
\hline \multirow[t]{2}{*}{ Log of \# employees at IPO } & 0.250 & -0.007 & 0.010 & $0.001 *$ & 0.000 & $0.151 * *$ \\
\hline & $(0.262)$ & $(0.033)$ & $(0.019)$ & $(0.001)$ & $(0.001)$ & $(0.053)$ \\
\hline \multirow{2}{*}{$\begin{array}{l}\text { F-test for industry fixed effect } \\
\text { (p-value) }\end{array}$} & 1.260 & 2.190 & 1.450 & 1.940 & 2.290 & 3.370 \\
\hline & $(0.268)$ & $(0.033)$ & $(0.181)$ & $(0.061)$ & $(0.026)$ & $(0.002)$ \\
\hline \multirow{2}{*}{$\begin{array}{l}\text { F-test for IPO-year fixed effect } \\
\text { (p-value) }\end{array}$} & 3.610 & 7.590 & 4.520 & 6.870 & 5.030 & 4.070 \\
\hline & $(0.000)$ & $(0.000)$ & $(0.000)$ & $(0.000)$ & $(0.000)$ & $(0.000)$ \\
\hline R-sq (within) & 0.073 & 0.159 & 0.075 & 0.209 & 0.215 & 0.178 \\
\hline (between) & 0.048 & 0.002 & 0.078 & 0.627 & 0.861 & 0.246 \\
\hline (overall) & 0.073 & 0.153 & 0.070 & 0.231 & 0.264 & 0.177 \\
\hline $\mathrm{N}$ & 592 & 607 & 564 & 607 & 564 & 592 \\
\hline
\end{tabular}


Table 17. Post-IPO Performance: Endogenous bank relationship

Notes. Dependent variable is the initial return. Each row shows the the estimated coefficient of the dummy variable, PreIPO loan \& bank-VC affiliation and the relevant statistics of each linear regression using various dependent variable. The linear models are estimated by the industry fixed-effect regression with IPO-year dummy variables and other control variables. The set of the control variables is the same as in Table 17. The instrumental variables excluede from the second stage regression is Metropolitan and pre-IPO tangibility. The outliers, which report the initial return in the top and bottom 1 $\%$, are dropped from the sample. The robust standard error is estimated by the industry cluster robust standard error. cient. Industry classification follows Table $4 . * * *$, and $* * *$ indicate that the estimated coefficient is different from zero at a $10 \%$, $5 \%$, and $1 \%$ statistical significance level, respectively (two-sided).

\begin{tabular}{|c|c|c|c|c|c|c|c|c|c|}
\hline Dependent Var. & $\begin{array}{c}\text { Est.Coef. of } \\
\text { Pre-IPO loan \& } \\
\text { bank-VC aff. }\end{array}$ & $\begin{array}{l}\text { Robust } \\
\text { S.E. }\end{array}$ & $\begin{array}{l}\text { Wald test of } \\
\text { excl. inst. }\end{array}$ & (p-value) & $\begin{array}{l}\text { Sargan Stat. } \\
\text { Chi-sq(1) }\end{array}$ & (p-value) & $\begin{array}{l}\text { R-sq of } \\
\text { 1st stage }\end{array}$ & $\begin{array}{l}\text { R-sq of } \\
\text { 2nd stage }\end{array}$ & $\mathrm{N}$ \\
\hline EBITDA/sales_1 & 7.593 & 5.311 & 35.35 & $(0.000)$ & 6.455 & $(0.011)$ & 0.188 & -0.090 & 607 \\
\hline EBITDA/sales_3 & 10.948 & 12.519 & 24.86 & $(0.000)$ & 1.837 & $(0.175)$ & 0.175 & 0.126 & 590 \\
\hline ROA_1 & -1.663 & 2.158 & 34.28 & $(0.000)$ & 0.209 & $(0.648)$ & 0.187 & 0.153 & 608 \\
\hline ROA_3 & 0.360 & 4.254 & 28.27 & $(0.000)$ & 1.046 & $(0.306)$ & 0.186 & 0.096 & 589 \\
\hline loan/asset_1 & 19.313 & $5.358 * * *$ & 34.00 & $(0.000)$ & 6.964 & $(0.008)$ & 0.189 & 0.201 & 620 \\
\hline loan/asset_3 & 24.673 & $7.294 * * *$ & 28.16 & $(0.000)$ & 4.952 & $(0.026)$ & 0.187 & 0.040 & 601 \\
\hline CAR_1 & -1.061 & 21.884 & 31.19 & $(0.000)$ & 0.255 & (0.613) & 0.186 & 0.166 & 606 \\
\hline CAR_3 & -71.622 & $31.080 * *$ & 25.25 & $(0.000)$ & 0.052 & (0.819) & 0.192 & 0.004 & 563 \\
\hline $\mathrm{SD}(\mathrm{AR}) \_1$ & -1.672 & $0.823 * *$ & 31.19 & $(0.000)$ & 2.096 & $(0.148)$ & 0.186 & 0.161 & 606 \\
\hline SD(AR)_3 & -1.293 & $0.543 * *$ & 25.25 & $(0.000)$ & 3.567 & (0.059) & 0.192 & 0.091 & 563 \\
\hline Sales growth & -52.498 & 44.662 & 29.14 & $(0.000)$ & 0.003 & (0.958) & 0.194 & 0.134 & 591 \\
\hline$\underline{\ln P D}$ & 0.717 & 0.849 & 31.40 & $(0.000)$ & 0.646 & $(0.422)$ & 0.200 & 0.067 & 591 \\
\hline
\end{tabular}

